No.1727

November 2020

\title{
School indiscipline and crime
}

Tony Beatton

Michael P. Kidd

Matteo Sandi 


\begin{abstract}
This paper studies the impact of compulsory schooling on violent behaviour and victimization in school using individual-level administrative data matching education and criminal records from Queensland (Australia). Exploiting a legislative increase in the minimum dropout age in 2006, this study defines a series of regression-discontinuity specifications to show that compulsory schooling reduces crime but increases violent behaviour in school. While police records show that property and drugs offences decrease, education records indicate that violence and victimization in school increase. Thus, prior studies that fail to consider in-school behaviour may over-estimate the short-run crime-reducing impact of compulsory education.
\end{abstract}

Key words: youth crime, minimum dropout age, school attendance JEL Codes: I2; K42

This paper was produced as part of the Centre's Community Wellbeing Programme. The Centre for Economic Performance is financed by the Economic and Social Research Council.

\title{
Acknowledgements
}

We would like to thank Peter Conroy and Sandra Smith from the Queensland Police Service (QPS), and Dr Angela Ferguson and Dr Mark McDonell from the Queensland Department of Education (DoE) for their help in negotiating access to their respective administrative data sets and enabling individual level data merging. We would also like to thank Abhijit Banerjee, Anna Bindler, Sandra Black, Peter Blair, Rui Costa, Emilia Del Bono, Richard Disney, Pascaline Dupas, Claudio Ferraz, Randi Hjalmarsson, Stephen Machin, Imran Rasul, Micaela Sviatschi, Ben Vollard, Felix Weinhardt and other seminar participants at the London School of Economics, NIESR, the LifeCourse Centre at the University of Queensland, the University of Glasgow, Jinan University, the 2018 International Workshop of Applied Economics of Education, the European Society of Population Economics Conference, the CEP (LSE) Glasgow Workshop on the Economics of Crime and Policing, the Asian and Australasian Society of Labour Economics Conference, the 2019 Royal Economic Society Conference, the 2019 ALCAPONE Conference, the IEB and the Universidad Carlos III for their feedback on our early results.

Tony Beatton, University of Queensland. Michael P. Kidd, RMIT University. Matteo Sandi, Centre for Economic Performance, London School of Economics.

Published by

Centre for Economic Performance

London School of Economics and Political Science

Houghton Street

London WC2A 2AE

All rights reserved. No part of this publication may be reproduced, stored in a retrieval system or transmitted in any form or by any means without the prior permission in writing of the publisher nor be issued to the public or circulated in any form other than that in which it is published.

Requests for permission to reproduce any article or part of the Working Paper should be sent to the editor at the above address.

(C) T. Beatton, M.P. Kidd and M. Sandi, submitted 2020. 


\section{Introduction}

In many countries, youth crime is a significant policy issue. Juveniles in the late teens and early twenties commonly exhibit high crime rates, and Australia is no exception. This may be not only because crime rates increase steadily until around age 18-20 and then decline later in life (Quetelet, 1831; and Landersø, Nielsen and Simonsen, 2016), but also because in most settings compulsory schooling terminates by age 18 and schools can no longer exert their protective factor that keeps juveniles away from crime. ${ }^{1}$

Increasing compulsory school attendance is often viewed as a means of delivering benefits to juveniles, one of which is reduced crime. Underlying this is the idea that, when juveniles are at school, they are kept busy in a supervised environment and their risk of committing crime is reduced. The link between crime and school attendance has been documented for most crime types and in a variety of settings, including the US (Jacob and Lefgren, 2003; Lochner and Moretti, 2004; Luallen, 2006; Anderson, 2014; Bell, Costa and Machin, 2016 and 2018; Cook and Kang, 2016), England and Wales (Machin, Marie and Vujic, 2011), Sweden (Hjalmarsson, Holmlund and Lindquist, 2015) and Australia (Beatton, Kidd, Machin and Sarkar, 2018).

This literature employs a variety of sources of exogenous variation in school attendance including idiosyncratic school closure dates for teacher training (Jacob and Lefgren, 2003) or teacher strikes (Luallen, 2006), as well as timing of school eligibility (Cook and Kang, 2016) and changes in the minimum dropout age (Lochner and Moretti, 2004; and Machin et al., 2011). The consensus is a beneficial crime-reducing effect from school attendance. A vast literature has also shown that an individual's educational experience and associated human capital acquisition have the potential to critically affect labour market prospects over the lifetime. $^{2}$

\footnotetext{
${ }^{1}$ The terms juvenile, youth and adolescent are used interchangeably throughout the paper.

2 Earnings returns to education have been shown in many countries, including Australia (Leigh, 2008), Canada (Oreopoulos, 2006; Albouy and Lequien, 2009), France (Grenet, 2013), Germany (Pischke and von Wachter, 2008), Norway (Black, Devereux and Salvanes, 2011), the UK (Harmon and Walker, 1995; Oreopoulos, 2006; Del Bono and Galindo-Rueda, 2007; Devereux and Hart, 2010; Dickson and Smith, 2011; Buscha and Dickson, 2012; Grenet, 2013; Dickson, 2013) and the US (Angrist and Krueger, 1991; Card, 1995; Card, 1999; Acemoglu and Angrist, 2001; Kling, 2001; Koop and Tobias, 2004; Lleras-Muney, 2005; Oreopoulos, 2006; Carneiro, Heckman and Vytlacil, 2011).
} 
What is currently less well-understood is how potential early dropouts respond to legislative change mandating one additional year in school. While one of the main rationales behind compulsory schooling is to improve the human capital and labour market prospects of potential early dropouts, the primary experience of compulsory education for such individuals is one of being forced to attend school surrounded by better-performing peers. ${ }^{3}$ Compulsory schooling laws often rest on a somewhat paternalistic view that juveniles wishing to drop out of school early are actually better off staying on (Messacar and Oreopoulos, 2012). However, if juveniles are at school against their will and they are not kept interested and engaged in learning, delinquent behaviour in school may increase without necessarily resulting in additional arrests. As a result, fellow students may suffer significant costs including increased bullying, gang activity, threats or at least a reduced perception of safety in school. $^{4}$

An increase in the compulsory schooling period may lead schools to internalize the delinquent behaviour of unruly juveniles, rather than directly reporting it to the police. In the United States (US), 1.4 million crimes were recorded in public schools in the $2015 / 16$ school year, with only 449,000 crimes, i.e. less than one in three, reported to the police (US Department of Education). ${ }^{5}$ Severe underreporting of in-school crime has been long documented in the US (Jeffrey, 2012; Trump, 2012; and Anderson, Hansen and Walker, 2013). In 2017, among students aged 12 to 18, the US Department of Education recorded approximately 827,000 total victimizations (theft and non-fatal violent victimization) at school, and roughly one in five students reported being bullied in school. ${ }^{6}$ According to the US School Survey on Crime and Safety, school administrators fail to report approximately $60 \%$ of all physical attacks without a weapon, more than $40 \%$ of violent crimes (excluding physical attacks without a weapon) and 32\% of illegal drug crimes (Gilpin and Pennig, 2015). In England, more than

\footnotetext{
${ }^{3}$ A growing literature has started to document the negative effects of exposure to higher-performing peers in school (Murphy and Weinhardt, 2018).

${ }^{4}$ The possibility that incapacitating people together may lead to increased violence has been raised also in other contexts, including the recent mandatory COVID-19 lockdowns throughout the world, and evidence has started to emerge in the US and elsewhere that incapacitating people at home has caused a sizeable increase in domestic violence (McCrary and Sanga, 2020; Leslie and Wilson, forthcoming; Carreras, Gibbons, Murphy, Perez-Vincent and Rossi, 2020).

${ }^{5}$ See https://nces.ed.gov/fastfacts/display.asp?id=49.

${ }^{6}$ See https://nces.ed.gov/pubs2019/2019047.pdf.
} 
30,000 school crime offences were recorded in $2015,{ }^{7}$ with the education system deemed in part responsible for the nationwide spate of fatal juvenile stabbings since $2017 .{ }^{8}$ This coincided with a record high in knife and sharp instrument homicides since the UK Home Office Homicide Index began in 1946. ${ }^{9}$ In Australia, from July 2015 to June 2016 the police proceeded against 55,000 young offenders (Australian Bureau of Statistics, 2017). As not all youth crime is reported to the police, prior studies that fail to consider in-school behaviour may over-estimate the crime-reducing impact of education in the short-run. Even if all in-school crime was fully reported, bullying would not be captured by police records. Generating an understanding of the educational experience of juveniles and how the legislation governing compulsory schooling affects their delinquent behaviour in school is therefore a first order research question in the economics of crime.

This paper studies the impact of compulsory education on delinquent behaviour in a novel way by examining a recent minimum dropout age (MDA) reform in Queensland (Australia) known as the "Earning or Learning" reform (hereafter EL). This was established in 2006 in the Australian state of Queensland. Through the EL reform, the MDA was raised from 16 to 17. Prior to 2006, students in Queensland were required to attend school up until either completing grade 10 or turning 16, whichever occurred first. The reform mandated that young people participate in a range of activities broadly defined as "Earning or Learning" for up to an additional two years, or until they turned 17. Juveniles were obligated either to stay in school or to participate in paid employment for at least 25 hours per week until turning 17.

Although an innovative policy, the EL reform has until recently been little analysed (see Beatton, Kidd, Machin and Sarkar, 2018). Analysis of the EL reform is useful to derive policy prescriptions that extend beyond Australia, as it shares many of the same features of US reforms that

\footnotetext{
${ }^{7}$ See https://www.bbc.co.uk/news/education-34268942.

${ }^{8}$ Figure A.1 in the Appendix reports one example of recent media coverage in the UK on the potential for compulsory schooling to increase violence in school. See also https://www.bbc.co.uk/news/education-47537631.

${ }^{9}$ Statistics on youth violence and knife crime can be consulted on the UK Office for National Statistics (ONS) website: https://www.ons.gov.uk/peoplepopulationandcommunity/crimeandjustice/articles/homicideinenglandandwales/yearendi ngmarch2018\#highest-number-of-sharp-instrument-homicides-seen-in-year-ending-march-2018.
} 
encourage participation in training or employment (see Oreopoulos, 2009; and Domnisoru, 2015). Similarly, the UK and numerous US states have recently implemented education reforms offering exemptions from minimum MDA laws based on proof of employment or volunteering status. ${ }^{10}$

The empirical analysis uses administrative data matched at the individual level for the years 2003 to 2013 across two agencies, the Queensland Department of Education (DoE) and the Queensland Police Service (QPS). ${ }^{11}$ Juveniles in the state school system are traced in terms of school and criminal activity from age 16 up until age 20 . Since the EL reform was enacted on the $1^{\text {st }}$ January 2006, the Intention-To-Treat (ITT) group in our analysis includes juveniles born from 1990-1993, while the ITT control group includes juveniles born from 1987-89. Thus, the impact of compulsory schooling on delinquent behaviour at age 16-20 is studied starting from the earliest cohort observed from age 16 up until the latest cohort observed until age 20 in our data.

Administrative records show that the EL reform had a significant impact on the dropout behaviour of juveniles in Queensland. Prior to the reform, the proportion of Queensland juveniles aged 15-19 in school was 72.5\%, well below the national average of 77.3\% (Australian Bureau of Statistics, 2003). The first-order effect of the EL reform was to increase the average time spent in school by a sizeable 0.3 years, an effect similar to that seen when the MDA was raised in Sweden (see Meghir, Palme and Schnabel, 2012; and Hjalmarsson, Holmlund, and Lindquist, 2015).

This study adopts a Regression Discontinuity (RD) approach to model delinquent behaviour as a function of distance to the relevant EL reform eligibility birth cut-off, post-cut-off indicator, their interaction term, and a variety of relevant individual and school characteristics. In the main analysis, criminal offences include administrative records from the Queensland Police for property damage and theft, drugs and violence. Measures of delinquent behaviour in school are derived from

\footnotetext{
${ }^{10}$ See https://www.gov.uk/know-when-you-can-leave-school.

${ }^{11}$ Examples of studies matching school records to crime records in the US, although with a different research focus, include Deming (2011), Billings, Deming and Rockoff (2014), Cook and Kang (2016) and Bacher-Hicks, Billings and Deming (2019).
} 
administrative records of the Queensland Department of Education and include School Discipline Sanctions (SDS) for property misconduct, drugs and violent misconduct. ${ }^{12}$

RD estimates show that the EL reform increased the count as well as the risk of receiving one or more violent SDS at age $16-17$ by approximately $18 \%$ and $12.5 \%$ respectively. These conclusions are shown to be robust to specification including varying sets of controls and fixed effects. Robustness in these conclusions also appears when adopting non-parametric RD methods and when alternative plausible sampling restrictions are made. ${ }^{13}$ An increase in violence on school premises, albeit to a lesser extent, also appears among youth aged 15, despite the fact that they are subject to compulsory school attendance both before and after the EL reform. This is consistent with both the concentration effect of school and, since the victims of youth violence are generally other juveniles (Jacob and Lefgren, 2003), with the victimization of younger students by older peers forced to stay in school longer. The increased in-school delinquent behaviour among 15 year olds also suggests that our findings are not simply the mechanical result of the longer time spent in school by juveniles exposed to the EL reform. Placebo estimates confirm the causal interpretation of our analysis, as no increase in violent behaviour appears when reform eligibility is artificially shifted back by one year to the 1989 birth cohort.

Police records of the same set of ITT juveniles show that exposure to the EL reform caused a reduction both in the count of property crime offences and in the likelihood to commit at least one property offence (0/1) at age 16-17 as well as at age 18-20. A similar crime-reducing effect of the EL reform is found for drug offences at age 16-17 and at age 18-20. In contrast, the EL reform led to no significant reduction of violent offences. However, as stated above, administrative school records on in-school delinquent behaviour reveal a sizeable increase in violence and victimization on school

\footnotetext{
${ }^{12}$ Queensland Education refers to these as School Disciplinary Absences (SDAs) because punishment normally takes the form of forced absence days from school. For clarity of understanding, here these are referred to as School Disciplinary Sanctions (SDS).

${ }^{13}$ A similar increase in delinquent behaviour is found when the analysis is restricted to "on time" students, defined as students enrolled in grade 10 at age 15 . Since compliance with school entry age requirements equates to being in grade 10 at age 15, these students were fully exposed to "the treatment" (the same terminology is used in Cook and Kang, 2016). Finally, our results remain unchanged when time-varying idiosyncratic school-specific shocks are controlled for via inclusion of school fixed effects interacted with school-year fixed effects.
} 
premises occurred as a result of the EL reform. Thus, while the EL reform reduced the propensity to commit property and drug criminal offences at age 16-17 and age 18-20, it also led to a significant upsurge in violence and victimization in school mostly unreported to the police.

The mechanisms underlying our findings could operate via a number of distinct channels, including idiosyncratic changes in school resources or in the costs and propensities of schools to punish. The findings suggest that none of these factors explain the in-school violence increase generated by the EL reform. Limited school capacity to absorb the extra enrolment of students following the policy is also an unlikely explanation of our findings, as class sizes do not significantly change and the level of school resources increased in the year of the reform. Finally, while we see an increase in violence, no systematic increase in the risk of other disciplinary sanctions is found. Analysis reveals no increase in the likelihood of property and drugs disciplinary sanctions, nor in other minor disciplinary sanctions, suggesting that our results do not reflect a mechanical relationship between compulsory schooling and receipt of disciplinary sanctions, nor the strategic effort by students forced to be enrolled at school for longer to receive SDS to skip school.

Additional analysis reveals that the EL reform disproportionately forced males, native speakers and low performers to stay at school, who featured higher early dropout rates prior to the reform. Since potential youth offenders are disproportionately male with little attachment to the labour market (Machin and Meghir, 2004), our results are consistent with the notion that schools internalise the delinquent behaviour of unruly juveniles. While the incapacitation effect of school on crime explains the reductions in property and drugs offences documented here and in several related studies, the conclusion that violence increased on school premises echoes the findings in Jacob and Lefgren (2003) and other recent studies reviewed in the next section, as a concentration and contagion effects seem to be at play here.

The remainder of the paper is structured as follows. Section 2 outlines the relevant literature. In doing so, it seeks to emphasise that in-school behaviour has been generally omitted by empirical studies of the crime-reducing impact of education in the short run. Section 3 describes the institutional 
setting of this study and the data. Section 4 describes the RD analysis of the impact of the EL reform on delinquent behaviour. Section 5 presents the main results, as well as a set of statistical tests to develop an understanding of the mechanisms underlying our findings. Section 6 presents additional evidence that compulsory education reduces crime and increases delinquent behaviour in school, and Section 7 derives policy prescriptions and concludes.

\section{School Indiscipline and Crime}

A large empirical literature finds that crime rates, particularly crimes against property, decrease sharply when juveniles are kept busy in supervised environments (Lochner, 2020). Such an incapacitation effect has long been the basis for schooling and other youth intervention programmes in the United States (see, e.g., Heller, 2014; and Heller, Shah, Guryan, Mullainathan and Pollack, 2017). More broadly, researchers have long sought to generate a comprehensive understanding of the causes of youth crime and the role education policy may play. A well-known difficulty in establishing the impact of education on crime is the endogenous nature of individual educational trajectories and the range of feedback effects by which crime affects education and vice versa.

Jacob and Lefgren (2003) first documented the contemporaneous reduction in property crime and increase in violence that occurs when school is in session. To circumvent the endogeneity of school attendance in the determination of youth crime, their study exploits exogenous variation in school attendance generated by day-to-day changes in school closures for teacher training purposes. Using data from the US National Crime Victimization Survey (NCVS), they show that crime in schools is reported less frequently than crime occurring elsewhere. Using 22 years of youth arrest data in Washington State, and unexpected school closures caused by teacher strikes, Luallen (2006) provides consistent evidence of the effect of school attendance on the day-to-day propensity of juveniles to commit crime: property crime decreases and violence increases when juveniles are in 
school. Due to data limitations, both papers study the impact of school attendance on contemporaneous crime at the locality level.

More recent studies of the contemporaneous effect of education on crime and in-school delinquent behaviour include Anderson, Hansen and Walker (2013), Anderson (2014) and Gilpin and Pennig (2015). Anderson, Hansen and Walker (2013) investigate whether minimum dropout age (MDA) reforms increase in-school crime in the US using self-reported data from the Youth Risk Behaviour Survey. They show that females and younger students report greater victimization when the MDA is raised. Thus, they show that who is in one's environment influences the likelihood of crime victimization even if, as is the case for MDA laws, it was not the choice of the potential victim to remain in school (Bindler, Ketel and Hjalmarsson, 2020). Anderson (2014) uses US county-level data to document that exposure to higher MDA laws reduces property and violent crime arrest rates for juveniles aged 16-18, compared to a control group of 13-15 year olds. His analysis of the Youth Risk Behaviour Survey data also suggests the potential for delinquency to move from the streets into schools, as stricter MDA laws result in young women missing more school out of fear for their safety. Using US school-level survey data to address a similar question, Gilpin and Pennig (2015) show an increase in overall in-school crime in US States that raise their MDA to 18, and no effect in States that raise it to 17 (relative to schools in states that do not).

These studies use self-reported survey data to study in-school delinquent behaviour and student victimization. While survey data has the obvious benefit of capturing information not usually present in primary source administrative data, self-reported survey data may suffer from measurement error (e.g., since respondents may have different reference points), potential recall biases in selfreported victimization, small and non-representative samples, selective responses, and lack of detailed information of the nature of the crime (Bindler, Ketel and Hjalmarsson, 2020). The current study overcomes these limitations by using confidential, high-quality, individual level data from the entire population of Queensland State School students. 
A large body of empirical evidence has also documented the crime-reducing role of MDA laws in the long run, particularly for males. Lochner and Moretti (2004) use state-level data from the US to show that greater exposure to compulsory education reduces lifetime incarceration. Machin, Marie, and Vujic (2011) use aggregate cohort data to show that the 1972/73 education reform in England and Wales, which raised the MDA from 15 to 16, decreased the risk of lifetime incarceration as it caused a significant reduction in property crime and a non-significant reduction in violent crimes. Fella and Gallipoli (2014) calibrate a life-cycle model using aggregate US data to show that raising high school graduation rates may be an efficient way to reduce crime. Bell, Costa and Machin (2016) use US data at the level of the commuting zone together with Census data to document the negative link between schooling laws and crime, measured either by arrests or incarceration.

Meghir, Palme and Schnabel (2012) and Hjalmarsson, Holmlund, and Lindquist (2015) were perhaps the first studies to use microdata to assess the crime-reducing impact of an MDA reform. This enabled scaling of the reduced form results by the effect of the MDA reform on years of schooling and thus provided results that are arguably free from general equilibrium effects that may bias previous estimates (Hjalmarsson, Holmlund, and Lindquist, 2015). Both studies analyse a schooling reform implemented gradually in the 1950s and 1960s across Swedish municipalities and show that the increased years of schooling caused by the reform resulted in a reduction in convictions and criminal activity. Unlike Hjalmarsson, Holmlund, and Lindquist (2015), Cano-Urbina and Lochner (2019) find a reduction in female criminality as a result of the US MDA reforms. Bell, Costa and Machin (2018) explore the reasons why increased education generates a reduction in crime, arguing that, by incapacitating juveniles at an age when the risk of committing crime is highest, MDA laws potentially modify an individual's entire crime-age profile.

Our findings also relate to existing evidence on the detrimental impact of exposure to negative peer effects in school, who have the potential to hinder school performance (Robertson and Symons, 2003; Figlio, 2007; Carrell and Hoekstra, 2010) and decrease future earnings (Carrell, Hoekstra and 
Kuka, 2018), while increasing the risk of drug use (Gaviria and Raphael, 2001; Kawaguchi, 2004; Lundborg, 2006; Powell, Tauras and Ross, 2005), cheating (Carrell, Malmstrom and West, 2008) and indiscipline in the classroom (Carrell and Hoekstra, 2010).

In addition, starting from Grogger (1997) and Aizer (2008), a recent literature documents the impact of exposure to violence on school performance. Brown and Velasquez (2017) document the harmful effect of the Mexican war on drugs on human capital accumulation. Monteiro and Rocha (2017) estimate the damaging effect on students' math scores caused by gunfights between drug gangs in Rio de Janeiro's favelas (slums). Bruck, Di Maio and Miaari (2019) show the damaging effect of the Israeli-Palestinian conflict on the educational trajectory of Palestinian high school students. Ang (2020) finds that exposure to police violence in the US generates lasting decreases in GPA, greater incidence of emotional disturbance, increased rates of high school dropout and reduced university enrolment. Koppensteiner and Menezes (forthcoming) show the negative effects of homicides on the way to school in Brazil on school attendance, on standardised test scores in math and Portuguese language and school completion rates, with the effects being particularly pronounced for boys. In Australia, the empirical setting of this study, evidence of the impact of violence on the mental health of victims and non-victims has been shown in Cornaglia, Feldman and Leigh (2014). ${ }^{14}$ A range of negative outcomes deriving from childhood exposure to violence also emerge from qualitative research. ${ }^{15}$

Despite the overall benefits of increased education, including reduced criminality, it is important to bear in mind that existing estimates of MDA laws do not fully consider the potential displacement of delinquency and violence from the streets into schools, nor the potential additional

\footnotetext{
${ }^{14}$ Discipline rules in school can be thought of as an integral part of the educational offer (Lazear, 2001). A recent literature also studies the consequences of school suspensions, with some studies finding positive effects due to the incapacitation of disruptive students (Figlio, 2007; Carrell, Hoekstra and Kuka, 2018) and the deterrence of anti-social behaviour (Kinsler, 2013), and other studies finding negative effects due to lost instructional time (Rivkin and Schiman, 2015), spillovers from grouping at-risk peers (Damm and Dustmann, 2014; Billings and Hoekstra, 2018) and increased risk of future criminal behaviour (Bacher-Hicks, Billings and Deming, 2018).

${ }^{15}$ Children exposed to violence display a greater risk of depression, anxiety, hyper-vigilance, avoidance, aggressive behaviour, delinquency, and a deterioration of cognitive performance (Cooley-Quille, Turner and Beidel, 1995; Smith and Tolan, 1998; Fowler, Tompsett, Braciszewski, Jacques-Tiura, and Baltes, 2009; Sharkey, Schwartz, Gould Ellen, Lacoe, Sørensen and Morgan, 2014).
} 
incidents of violence and bullying within schools. As a number of existing studies highlight (e.g., Anderson, 2014), this is an important research question to consider. This paper aims to rectify this omission in the existing literature by providing the first empirical analysis of the effect of compulsory schooling on in-school delinquency using education and criminal administrative records of juveniles linked at the individual level. Availability of these data for the entire population of students in state schools in Queensland allows us to link administrative behavioural records in school with administrative criminal records during, as well as after, the compulsory schooling period.

This paper makes three significant contributions to the literature. First, while existing studies of youth delinquency use survey data to study in-school behaviour, availability of administrative records from both the Queensland Police Service and Department of Education allow us to compare the contemporaneous youth delinquent behaviour in and out of school caused by an MDA reform. Second, while existing studies rely on self-reports of victimization or on reports by school administrators, this study derives novel insights on the perpetrators of in-school delinquent behaviour, and how their in-school behaviour links with criminal behaviour outside school both during and after the end of secondary school. Third, this study shows that, in addition to greater victimization, students experience a contagion effect as younger students also become more likely to display violent behaviour when older unruly juveniles are forced to attend school for longer.

\section{Institutional Framework and Data Description}

\subsection{The Queensland Education System and the Earning or Learning Reform}

The institutional setting of this study is the state of Queensland in Australia. Approximately three quarters of students attend the state-run school sector, which is funded by the State and Federal Australian Governments (QGOV, 2018a), while the remainder attend private schools. The school year runs from the third week of January to mid-December, and administrative rules imply that children are expected to start grade one in the calendar year in which they turn six years of age 
(QGOV, 2018b). Children attend up to 12 years of education (grades 1 to 12), with primary school consisting of grades 1 to 7 and high school grades 8 to $12 .{ }^{16}$ At the end of secondary school, students are expected to sit high-stakes exams to obtain an Overall Position (OP) certificate to enter university or attain a Queensland Certificate of Education.

The 2006 Queensland “Earning or Learning” (EL) reform modified the legislation governing dropout behaviour. Prior to 2006, school attendance was mandatory until either completing grade 10 or turning 16 years old, whichever occurred first. The EL reform raised the minimum dropout age (MDA) from 16 to 17 . This additional year of compulsory education was to be spent either in school, vocational training, or in a full-time job. The EL reform introduced a compulsory obligation forcing juveniles to participate in a range of activities broadly defined as "earning or learning" for up to an additional two years, or until they turned 17 years old. Juveniles were forced to either stay on at school until obtaining a high school Senior Certificate or a vocational education Certificate III, or to participate in paid employment for at least 25 hours per week until age 17 . The intention of the policy was to help the school-to-work transition and boost the labour market prospects of juveniles, with the underlying idea that education and training can offer the skills needed to succeed in adult life and widen the employment options available to juveniles over their lifetimes. ${ }^{17}$

The Queensland school system and the EL reform display similarities with the legislation governing compulsory schooling in other states of Australia, in the UK and the US. Similar to the EL reform in Queensland, recent education reforms in the US and UK have broadened the scope of legislation to boost participation in training or employment (see Oreopoulos, 2009, and Domnisoru, 2015, for evidence from the US). ${ }^{18}$ Offender rates in Queensland have been comparable to the

\footnotetext{
${ }^{16}$ In 2015, i.e., after the end of our study period, the school enrolment window changed. According to the current legislation, a child enrolling in grade one must turn six between the $1^{\text {st }}$ July in the year prior to enrolment and the $30^{\text {th }}$ June in the year of enrolment. Since 2015, grade 7 also forms part of high school grades.

${ }^{17}$ In a media statement delivered in November 2005, the Queensland Education Minister Rod Welford stated: "From 1 January 2006, when the Act comes into effect, the compulsory school age will increase and young people will be required to be 'learning or earning' until they turn 17. We want to help keep young people learning, or to help them return to learning, so they can gain the skills and qualifications they need to succeed in later life." (see http://statements.qld.gov.au/Statement/Id/43712).

${ }^{18}$ See https://www.gov.uk/know-when-you-can-leave-school.
} 
Australian national average over the last two decades (Australian Bureau of Statistics). ${ }^{19}$ Thus, the EL Reform provides a valuable policy experiment to study the impact of MDA reforms on youth delinquent behaviour in and out of school and derive policy prescriptions that extend beyond Queensland.

\subsection{Data}

Our analysis uses administrative data matched at the individual level from two agencies, the Queensland Department of Education (DoE) and the Queensland Police Service (QPS). This confidential, high-quality linked dataset was constructed in collaboration with the DoE and QPS, and it includes individual record data for the population of Queensland Government funded school attendees together with matched individual criminal offence data on juveniles and young adults for the period 2003 to 2013 .

Queensland Police Service (QPS) records refer to alleged criminal offences in a given year by individuals aged 16 to 20 . An alleged offender is a person who has allegedly committed a crime and has been charged by the police by arrest, caution, warrant or apprehension. In the empirical analysis, the main outcomes of interest are property, drug and violent criminal offences by an offender in a given year. Property offences include criminal damage, as well as theft and handling of stolen goods. Violent offences include violence against the person, sexual offences and robbery.

The crime data are matched at the individual level to the administrative Queensland schooling data from 2003 to 2013. School disciplinary sanctions (SDS), i.e., school suspension records from the DoE, are used to measure behaviour in school. SDS are actions in response to serious breaches of school rules and unacceptable behaviour that are available to Queensland school principals in order to restore discipline. Reasons for SDS include property misconduct, such as destruction or theft of school property or the property of others on school premises; substance misconduct involving illegal substances, such as drugs; and physical misconduct, including violence against other students or

\footnotetext{
${ }^{19}$ These statistics can be accessed on the website of the Australian Bureau of Statistics here.
} 
against school personnel. ${ }^{20}$ In any one year, principals may discipline students with multiple short suspensions of 1 to 5 days or multiple long suspensions of 6 to 20 days. ${ }^{21}$ Principals may also expel a student from school in response to extreme and repeated bad behaviour. The allocation of SDS is moderated by the Queensland Education head office in order to ensure consistency in discipline sanctions, independent of school-specific and school principal-specific propensities to assign discipline sanctions.

Table 1 shows the structure of the administrative panel dataset used in the main analysis. Since the crime data is matched at the individual level to the schooling data from 2003 to 2013, complete information on delinquent behaviour is available for a balanced panel of individuals aged 16-20 from the 1987-1993 birth cohorts. Earlier cohorts could not be observed since the age of 16, i.e., the MDA prior to the EL reform, and later cohorts could not be followed up to age 20. School enrolment data for the 1987-1993 birth cohorts is also available at age 15. In fact, while crime and school enrolment records exist from 2002, no SDS records are available for the 2002 school year. Thus, the analysis is conducted on the 2003-13 school years for which complete information on delinquent behaviour in and out of school is available. All juveniles included in the analysis were in the state school system at least once from age 15-17.

Figure 1 shows for each secondary state school in Queensland the average count of property, drug and violent crime offences from police records at age 16-20 per individual plotted against the average count of property, drug and violent misconduct from school records at age 16-17 per individual. Figure 1 exhibits a strong positive correlation, suggesting that police records and school discipline records reflect similar behavioural traits. Figure 2 also shows that similar individual characteristics predict delinquent behaviour in and out of school. In particular, the dropout age of an

\footnotetext{
${ }^{20}$ Administrative school records also include information on other less serious types of misconduct that may result in the receipt of an SDS, including truancy, persistent disruptive behaviour, verbal and non-verbal misconduct, refusal to participate and misconduct involving legal substances, i.e., cigarettes or alcohol (QGOV, 2018c). These less serious SDS categories are brought later into the empirical analysis to analyse the mechanisms behind our findings.

${ }^{21}$ The definition of short suspension has been modified in 2015 , i.e., after our study period ends, and it now includes suspensions lasting from 1 to 10 days.
} 
individual appears negatively correlated with the likelihood to commit criminal offences at age 1820 and age 16-17, as well as to receive SDS at age 16-17. This negative correlation appears sensible, as it reflects the positive selection in the highest school grade attended and the negative selection in criminal activity and receipt of SDS. Males and native English speakers appear more likely to engage in delinquent behaviour in and out of school. Juveniles born towards the end of the calendar year appear less likely to commit crime at age 16-17 than peers born at the beginning of the calendar year, but they appear more likely to receive SDS at age 16-17 and to commit crime at age 18-20. Youth aged 16 appear more likely than youth aged 17 to receive SDS and slightly less likely to commit crime, which seems consistent with the incapacitation effect of school since in our data compulsory schooling ends at age 17. Juveniles aged 19-20 appear less likely to commit crime than their younger peers aged 18, which is consistent with the notion that criminality peaks in the late teens and then declines (Quetelet, 1831; and Landersø, Nielsen and Simonsen, 2016). Table 2 presents descriptive statistics for the outcomes of interest separately by age. In total, the main empirical analysis includes 282,702 juveniles aged 16-20 and 1,412,758 juvenile-year observations. Table 2 confirms that, while juveniles face a greater risk of receiving SDS at age 16, they face a greater risk of criminal participation at ages 17-18 and then a reduced risk at subsequent ages.

\section{Empirical Strategy}

The Earning or Learning (EL) reform was enacted on the $1^{\text {st }}$ January 2006 and the first cohort to be directly affected by the legislative change was born in the year 1990. Thus, the impact of the EL reform on crime and in-school delinquency can be quantified by defining a series of Regression Discontinuity (RD) specifications whereby the Intention-To-Treat (ITT) status is defined by birth cohort. The delinquent behaviour at age 16-20 of ITT juveniles born in 1990-93 is compared with that of control juveniles born in 1987-89. Delinquent behaviour is modelled as a function of distance in year of birth to the relevant birth cut-off determining EL eligibility, post-cut-off indicator (i.e., born in 1990-93), their interaction term, and a variety of individual and school characteristics. 
A series of ITT estimates of the impact of the EL Reform on delinquent behaviour is presented. Information on the school leaving grade of individuals is also available in our data, and therefore the first-order effect of the EL Reform on the youth dropout behaviour could also be estimated. However, instrumenting the dropout behaviour of juveniles with the EL reform would require us to assume that the only channel through which the reform affected crime and delinquent behaviour in school is years of schooling and not via other aspects of the reform, such as changing peer group. This does not appear a tenable assumption for our analysis, since behavioural outcomes are measured from age 16, i.e., at a younger age than the MDA introduced by the EL reform, and thus greater exposure to older unruly peers is a potential mechanism through which the EL reform may increase delinquency and victimization in school. Thus, no instrumental variable (IV) estimates are presented.

Formally, the ITT impact of the EL reform on the dropout behaviour, crime and SDS of juvenile $i$ from birth cohort $c$ in school year $t$ is estimated as follows:

$$
Y_{i c t}=\alpha+\beta_{1} * E L_{i c}+\beta_{2} * Y o b_{i c}+\beta_{3} * Y o b_{i c} * E L_{i c}+f(a, t)+\delta * X_{i c t}+\vartheta_{s}+\omega_{i c t}
$$

where $Y$ is the outcome of interest, with crime calculated separately at age 16-17 and age 18-20, and SDS calculated at age 16-17. EL is a binary variable that takes the value 1 for juveniles born in 199093 who were subject to the EL reform, and value 0 for juveniles born $1987-89$. $Y o b$ is a continuous indicator of distance from juvenile $i$ 's year of birth to the 1990 year that is included in all specifications together with its interaction with the $E L$ variable and with $\mathrm{f}(\mathrm{a}, \mathrm{t})$, which is a function of the individual's age (a) and school year ( $\mathrm{t})$. In all estimated specifications, $\mathrm{f}(\mathrm{a}, \mathrm{t})=a_{t-c}+a_{t}$ is modelled by a full set of age (where $a=\mathrm{t}-\mathrm{c}$ ) and school year dummies $a_{t-c}$ and $a_{t} . X$ is a vector of time-invariant individual characteristics including gender, native language and day-month of birth. $\vartheta$ is a set of school fixed effects measured at age 15 , and $\omega$ is the error term. In (1), the key parameter of interest is $\beta_{1}$, the estimated coefficient on the Earning or Learning reform variable EL, which is defined by birth cohort as previously described. In (1), once fixed effects for gender, native language, day-month of birth, age and school year have been taken into account, together with heterogeneous 
linear trends by year of birth either side of the discontinuity window, estimates of $\beta_{1}$ show the shortrun RD impact of the EL reform on delinquent behaviour of juvenile $i$ from birth cohort $c$ in school year $t$. Thus in (1), $\beta_{1}$ identifies the different propensity to commit crime or receive SDS of juveniles marginally separated by eligibility for the EL reform in a given school year, at a given age, and with a given set of individual characteristics. ${ }^{22}$ Standard errors are clustered at the date of birth level since the dropout behaviour in Queensland is defined in terms of age and not grade completion. Thus, while individuals born on the same date are subject to the same compulsory schooling period, individuals born on different dates in the same year may face up to almost a one-year difference in the timing of dropout eligibility depending on the date of birth within a given year. In this regard, the MDA legislation in Queensland resembles the legislation in North Carolina and other US states (see Cook and Kang, 2016).

\section{Empirical Findings}

\subsection{Unconditional Estimates}

The starting point in the econometric analysis is to show that juveniles born in 1987-89 provide a suitable control group for those born in 1990-93. Table 3 shows a set of balancing tests of the distribution of individual characteristics across the 1990 cut-off (i.e., the year-of-birth cut-off determining eligibility for the Earning or Learning (EL) reform). Each individual variable was regressed on the EL indicator (i.e., born in 1990-93), a continuous control for distance in year of birth to the 1990 cut-off and their interaction term. Results from OLS are shown in column (1), while

\footnotetext{
${ }^{22}$ Since the data contains individual-level information on the exact date of birth of individual $i$, in principle it would be possible to define the running variable based on the exact date of birth and conduct the analysis controlling for a continuous indicator of distance from juvenile $i$ 's exact date of birth to the $1^{\text {st }}$ January 1990 , together with its interaction with the $E L$ variable. However, this is not done here because this empirical strategy would result in our estimates possibly picking up two separate effects: namely, the impact of exposure to the EL reform and the impact of being born at the end of the calendar year on delinquent behaviour (see Cook and Kang, 2016; and Landers $\varnothing$, Nielsen and Simonsen, 2016). While the former parameter is best estimated comparing delinquent behaviour across year-of-birth cohorts in this section, the latter parameter is estimated separately in Section 6 below to provide additional evidence on the impact of compulsory schooling on delinquent behaviour in and outside school.
} 
results from Non-Parametric RD Estimates using a Uniform Kernel and a Triangular Kernel are shown in columns (2) and (3) respectively.

All estimation methods suggest that ITT treatment and control groups are balanced on observable characteristics. On average, ITT treatment and control groups have a similar age and fraction of males and native speakers. Male native speakers also appear equally distributed across groups. "Off time" students, defined as students not attending grade 10 at age 15, i.e., the expected school grade based on the year of birth prior to reaching the dropout age, appear similarly distributed across groups, and the same conclusion also applies to "off time" male students and "off time" native speakers. ITT treatment and control group youths were born on similar days-months of the year, and this holds true also for males and native speakers only.

Figure 3 shows the average dropout grade from the raw data by year of birth for the entire population of juveniles in the analysis. The dropout grade is defined as the highest grade in which an individual is observed to be enrolled in state-maintained schools in Queensland. While the average dropout grade appears at 11.58 for the $1987-89$ cohorts, the average dropout grade of the 1990-93 cohorts is 11.87 . Thus, a significant increase in the average dropout grade of 0.29 units appears between the 1987-89 and 1990-93 cohorts. This is a similar order of magnitude to the effect on years of schooling of the education reform in Sweden studied by Meghir, Palme and Schnabel (2012) and Hjalmarsson, Holmlund, and Lindquist (2015), and represents a sizeable $2.5 \%$ increase in the average dropout grade.

Figure 4 displays raw data on both the average count and the average likelihood to receive one or more School Discipline Sanctions (SDS) per individual at age 16-17 by year of birth (Panel A and Panel B respectively). SDS include property misconduct SDS, illicit substance SDS and violent SDS received per youth in a year. While both the count and likelihood of SDS appear lower for the 1989 cohort than for the 1987 cohort, starting from the 1990 cohort an upward trend appears with the ITT treatment cohorts displaying a significantly higher likelihood of receiving disciplinary sanctions in school. 
Figure 5 displays raw data on violent behaviour, and it shows the average count and average likelihood of receiving violent SDS per individual at age 16-17 by year of birth (Panel A and Panel $\mathrm{B}$ respectively). Here the greater prevalence of discipline sanctions among ITT treatment cohorts appears even more evident. While violent SDS appear fairly stable for the 1987-89 cohorts, cohorts born in 1990 display a significantly higher propensity towards violent behaviour in school. ITT control juveniles faced a $1.6 \%$ prevalence of violent SDS on average, compared with an average ITT treatment prevalence of $1.9 \%$. This represents approximately a $17 \%$ increase among youth aged 16 17 coinciding with the EL reform. This increase in delinquent behaviour and violence in school is not limited to the 1990 cohort and it appears common to all cohorts subject to the EL reform, suggesting that it does not reflect a temporary shock to schools in the immediate follow up of the reform.

\subsection{Conditional Estimates}

Table 4 subjects these unconditional estimates to a more rigorous econometric analysis. In particular, results are presented from a set of regression discontinuity (RD) specifications estimated to separate the causal impact of the EL reform on in-school delinquency from the effects of other confounding factors that may affect the unconditional findings from the raw data in Figures 3-5. In Table 4, OLS estimates are presented separately for property misconduct SDS in columns (1)-(3), drugs SDS in columns (4)-(6) and violent SDS in columns (7)-(9). For each category of SDS, estimates of the impact of the EL reform on the count of SDS are presented in Panel A, i.e., including both extensive and intensive margin effects of the EL reform on SDS, with estimates of the impact of the EL reform on the likelihood of receipt of one or more SDS presented in Panel B, i.e., the extensive margin effect of the EL reform on SDS. In all cases, the outcome of interest was regressed on a binary indicator of eligibility for the EL reform (i.e., born in 1990-93), a linear trend for year of birth, their interaction (thus allowing for heterogeneous trends either side of the EL cut-off), as well as age fixed effects and school-year fixed effects. Estimates in columns (2), (5) and (8) also control for individual-level characteristics, i.e., gender, native language and day-month of birth, while estimates in columns (3), (6) and (9) additionally control for school fixed effects measured at age 15. 
Table 4 shows that the EL reform did not cause an increase in property SDS or drugs SDS. This conclusion emerges whether the extensive or the intensive margin effect of the EL reform is studied, and it appears robust to the set of controls and fixed effects included in the specification. However, a significant increase in violence appears as a result of the EL reform. This conclusion is robust to the set of controls and fixed effects included in the estimated equation. The EL reform led to approximately a $17 \%$ increase in the count of violent sanctions received at age $16-17$, and it increased the likelihood of facing at least one violent SDS at age $16-17$ by $12.5 \%$. The bottom row of Table 4 shows the first-order effect of the EL reform on the dropout grade of juveniles using the same specifications across columns as in the main analysis described above. Regardless of the set of controls included in the econometric analysis, a significant increase in the average dropout grade also appears in Table 4. Thus, estimates in Table 4 largely confirm the unconditional descriptive findings in Figures 3-5.

As no impact of the EL reform is found on the propensity of juveniles to receive property or drugs SDS, the rest of the analysis in this section focuses on violent SDS. Table 5 shows that the conclusion that the EL reform led to increased in-school violence is robust to estimation method. Results from Non-Parametric RD Estimation using a Uniform Kernel and Triangular Kernel functions are presented in Columns (1)-(3) and (4)-(6) respectively. Table 5 is organised in similar fashion to Table 4 and the same set of control variables are progressively added to the basic RD specification in columns (1) and (4), i.e., heterogeneous trends by year of birth either side of the EL cut-off, age fixed effects and school-year fixed effects. Non-parametric estimates in Table 5 appear as a strong replication of parametric estimates for violent SDS in Table 4, suggesting that these results are robust to equation specification and estimation method.

Table 6 tests the robustness of our estimates for violent SDS to sampling restrictions, as the impact of the EL reform is estimated again without "off time" students. As stated above, these are defined as students not attending grade 10 at age 15, i.e., the expected school grade based on the year 
of birth prior to reaching the dropout age. ${ }^{23}$ Thus, only "on time" students are included in the analysis in Table 6. Since "on time" students have started school in the expected year and did not have to repeat a grade prior to age 16 , they can be thought of as more academically gifted than their peers on average. As the practice of "redshirting", i.e., postponing school entry in the year a child is expected to start school, and grade repetition are obviously not random events, this appears as a strict sampling restriction and therefore it is not incorporated in the main analysis. However, this test is presented because our ITT measure is based on the year of birth, and thus "on time" students were fully exposed to "the treatment". Reassuringly, our conclusion that in-school violence increased among youth aged 16-17 finds empirical support in the results in Table 6. The Table is organised similarly to Tables 4 and 5, as the extensive and intensive margin estimated effects of the EL reform on violence are displayed in Panel A, the extensive margin estimated effects of the EL reform on violence are displayed in Panel B, and the same set of varying controls is progressively added to the estimated equation across columns. Estimates in Table 6 do not appear statistically distinguishable from those in columns (7)-(9) of Table 4 and in Table 5, and they confirm that in-school violence increased as a result of the EL reform.

Finally, Table 7 presents placebo estimates of the impact of the fake EL reform shifted back to 1989 , i.e., by one birth cohort, on violent SDS at the extensive and intensive margin in Panel A, and at the extensive margin in Panel B. Estimates in Table 7 are obtained from OLS regression specifications, the Table is organised similarly to Tables 4, 5 and 6 and the same set of varying controls is progressively added to the estimated equation across columns. Standard errors were clustered again at the date of birth level. Reassuringly, estimates in Table 7 appear statistically insignificant and numerically much smaller than those presented in Tables 4, 5 and 6 for violent SDS. This conclusion confirms the impression from the visual inspection of Figure 5, where no increase in violence in school appears among control cohorts who were not exposed to the EL reform.

\footnotetext{
${ }^{23}$ Table 3 shows these to be similarly distributed across ITT treatment and control groups, and they are excluded from the analysis in Table 6.
} 


\subsection{Discussion and Mechanisms}

Why did the EL reform induce an increase in youth violence in school? The findings in Tables 4-6 are consistent with the notion that schools internalise the violent behaviour of juveniles forced to stay in school for one additional year when the minimum dropout age (MDA) is raised from 16 to 17. However, a number of alternative explanations underlying this result are also possible. Thus, a set of potential confounding factors are investigated empirically in this section. None of them turn out to represent plausible explanations for the increase in violence on school premises generated by the EL reform.

Firstly, the EL reform and the resulting school enrolment of one additional cohort may have put pressure on school facilities and personnel, generating a temporary increase in school suspensions. However, limited school capacity to absorb the extra enrolment of students at the onset of the policy appear as an unlikely explanation of our findings, given that a lasting increase in violence up until the 1993 cohort is evident in Figures 4 and $5 .{ }^{24}$ Secondly, the EL reform may have coincided with other idiosyncratic time-varying school-specific shocks that are not observed in our data, e.g., in school resources, in support programmes, or even in school principals. These changes may have also altered the propensity of school principals to punish, thus modifying the interpretation of the estimates for violent SDS in Tables 4-6.

A systematic increase in the likelihood of schools to punish appears unlikely, given that no increase in property and drugs SDS appear in Table 4. Moreover, the analysis of other, minor infractions is presented in Table 8 and it confirms this conclusion. In particular, Table 8 presents estimates of the impact of the EL reform on the count of less serious types of misconduct that may result in the receipt of an SDS, including truancy, verbal and non-verbal misconduct, persistent disruptive behaviour and refusal to participate, and misconduct involving legal substances, i.e., cigarettes or alcohol. If the estimates in Tables 4-6 for violent SDS reflected the increased propensity

\footnotetext{
${ }^{24}$ Descriptive analysis comparing school resources pre and post EL reform also shows that, on average, school resources significantly increased after the EL policy.
} 
of schools to punish, rather than a genuine increase in violence, a generalized increase in the count of SDS would appear for juveniles who were subject to the EL reform. However, this is not what is found here. Estimates in Table 8 demonstrate no systematic change in the count of truancy SDS, nonverbal misconduct SDS, persistent disruptive behaviour and refusal to participate in instruction SDS, and misconduct involving legal substances SDS. Similar to the estimates in Table 4 for property and drugs SDS, estimates for these outcomes appear statistically and numerically indistinguishable from zero, thus mitigating the concern that schools systematically increased their propensity to punish after the EL reform. The only exception is an increase in verbal misconduct among ITT juveniles born in 1990-93, which in fact arguably represents a form of verbal violence. The results in Table 8 also mitigate the concern that students exposed to the EL reform made a strategic effort to be suspended from school. If this was the case, a systematic increase in the rate of receipt of any type of SDS would appear in our data. Table 8 provides no empirical support of this hypothesis.

Absent a systemic increase in the propensity of schools to punish following the EL reform, one may nonetheless worry that schools may have decided to adopt a stricter disciplinary approach specifically in response to violent behaviour. If this was the case, the estimates in Tables 4-6 would reflect the stricter discipline approach of schools and their greater propensity to punish this specific type of delinquent behaviour, rather than a genuine increase in in-school violence. As stated above, although our data does not identify a principal's decision process to punish misbehaviour, the allocation of SDS is moderated by the Queensland Education head office in order to ensure consistency in disciplinary actions. Moreover, in order to further mitigate both this concern and the more general concern that time-varying idiosyncratic unobserved school-specific shocks may underlie our results, a set of interactions between school fixed effects and school-year fixed effects are added to the main analysis on violent SDS in Table 4. With the inclusion of these interactions, the only variation left is variation within school and school-year coming from the eligibility to the EL reform of ITT juveniles born in 1990-93. 
The results from this exercise are presented in columns (1) and (2) of Table 9. In particular, column (1) shows estimates of the impact of the EL reform on violent SDS when school fixed effects are interacted with a binary variable that takes value one in the school years starting from 2006 (i.e., since the EL reform came into force), and zero otherwise. In column (2), school fixed effects are interacted with school-year fixed effects, thus controlling for any school and school-year specific shock. As in Tables 4-6, the extensive and intensive margin effects of the EL reform are investigated in Panel A, while only the extensive margin is investigated in Panel B. Estimates in columns (1) and (2) of Table 9 strongly replicate estimates for violent SDS in Table 4. All the hypothesised factors above, i.e., limited school capacity in 2006 , changes in disciplinary policies in response to violence, in school resources, in support programmes or in school principals, should be common to all students in a given school in a given year, and thus they should be captured by the set of interactions between school fixed effects and school-year fixed effects. It seems implausible that, within a given school and school-year, these hypothesised factors would affect differently observably similar ITT treatment and control juveniles only in relation to their violent behaviour. Thus, estimates in Tables 4-6 and in Table 9 are unlikely to result from any of these confounding factors.

One may also wonder whether the EL reform simply moved violent behaviour from outside to inside schools, or whether a concentration effect causing a genuine increase in violence is at play. Similarly, one may worry that the increased violence in school documented in Tables 4-6 is simply the mechanical effect of the longer time spent in school by juveniles as a result of the EL reform, and that the violence taking place in school after the EL reform would have taken place anyway outside school. One way to test this is to study the impact of the EL reform on the violent behaviour of juveniles aged 15. A benefit of restricting analysis to this group is that it ensures our results are not driven by students who are kept in school because of a change in the MDA law. ${ }^{25}$ These juveniles were not included in the analysis presented so far as those born in 1987 are only observed since the

\footnotetext{
${ }^{25}$ A similar exercise is presented in Anderson, Hansen and Walker (2013).
} 
age of 16. Thus, inclusion of juveniles aged 15 in the analysis would have resulted in an unbalanced panel dataset with an older ITT control group and a younger ITT treatment group. However, in order to check whether the results in Tables 4-6 simply reflect a shift in the locality of violent crime, but not a genuine increase, a statistical exercise was conducted without the 1987 cohort and focusing on the 1988-93 cohorts observed at age 15 .

Columns (3), (4) and (5) of Table 9 show OLS estimates of the impact of the EL reform on the violent behaviour in school of juveniles aged 15. Regardless of the equation specification and the set of controls and fixed effects included in the analysis, results in Table 9 suggest that the EL reform increased the count of violent SDS of juveniles aged 15, albeit to a lesser extent compared with the main effect on the violent behaviour of juveniles aged 16-17. Panel B shows that no effect appears at the extensive margin, arguably suggesting that the results in Panel A are driven by relatively few prolific youth violent offenders. Since juveniles aged 15 were always forced to stay in school before and after the EL reform, these findings indicate that schools experienced a genuine increase in school violence and they are consistent with a concentration effect of school on violence. It is also possible that the increased violence among 15 year olds reflects greater victimization of students due to the increased presence of their older unruly peers in school.

Another way to study whether the increase in in-school violence generated by the EL reform reflects a genuine rise in violence is to examine the impact of the EL reform on criminal offences using police records. Table 10 presents ITT estimates of the impact of the EL reform on crime and SDS by category. The table is organised in a similar way to Tables 4-6, and exactly the same OLS equation specification with the full set of fixed effects is estimated again. Columns (1)-(3) focus on property crime and SDS, with column (1) focusing on property crime at age 18-20, column (2) on property crime from age 16-17 and column (3) focusing on property SDS at age 16-17. Columns (4)(6) are organised in the same way and focus on drug offences, while columns (7)-(9) do likewise for violent crime. Panel A shows the impact of the EL reform on the counts of criminal offences or SDS, 
while Panel B shows the impact of the EL reform on the likelihood of one or more criminal offences or SDS.

Results in columns (1)-(6) in Table 10 show that the EL reform unambiguously reduced property and drug offences at the extensive and intensive margins both at age 16-17 and at age 1820. This conclusion is consistent with the large literature that documents the crime-reducing role of compulsory school attendance. The crime reduction at age 16-17 results primarily from the incapacitation effect of school on property and drugs crime, while the crime reduction at age 18-20 arguably reflects the better labour market prospects of more educated individuals and the reduced stigma and recidivism of juveniles exposed to the "protective factor" of schooling for longer (Mendel, 2011; Aizer and Doyle, 2015; Stevenson, 2017; Mueller-Smith and Schnepel, forthcoming).

In columns (7) and (8), police records suggest that violent crime was not affected by the EL reform. This clearly contrasts with the conclusion from column (9), where school records are used to document a sizeable increase in violence on school premises. The relevance of these findings is threefold. First, the fact that no change in violent crime appears from the police records suggests that the EL reform caused a genuine increase in school violence that is consistent with a concentration effect of school on violence, and not just a displacement of violence from outside to inside school. One caveat is that violent crime records from the Queensland police and violent SDS from the Queensland Education Department may not capture the same violent acts. However, the fact that police records detect no reduction in violence while detecting sizeable reductions in property and drug offences does suggest that violence was not simply displaced across space due to the EL reform. Secondly, the fact that police records detect no change in violence while education records document a sizeable increase suggests that schools internalised the increase in violence and victimization caused by the EL reform and the increased delinquent behaviour was largely unreported to the police. Finally, these findings reflect the importance of combining school and police records, and show that omission 
of in-school violence will tend to over-estimate the scale of crime-reduction, and therefore the desirability, of MDA laws in the short run. ${ }^{26}$

In order to understand how the EL reform may have changed the school environment, Table 11 investigates which individuals and schools were mostly affected by the MDA law change. It shows OLS estimates of the impact of the EL reform on the individual and school characteristics of juveniles in school at age 16-17. Results in Table 11 suggest that the EL reform acted disproportionately upon males, native speakers and "off time" students. Any interaction between these characteristics is also disproportionately represented in the student population following the EL reform, suggesting that the share of these juveniles in the population of enrolled students at age $16-17$ increased by $7-10 \%$ as a result of the EL reform. Moreover, the EL reform had a greater impact on students in larger classes, in classes with a higher male share and in more resource-deprived schools. These school and class characteristics were measured at age 15 . Since potential youth offenders are disproportionately male and with little attachment to the labour market (Machin and Meghir, 2004), these results are consistent with the notion that schools internalised the delinquent behaviour of unruly juveniles as a result of the EL reform.

\section{Early School Eligibility, School Indiscipline and Crime}

Are "off timers" actually more likely to misbehave in and outside school? Minimum Dropout Age (MDA) laws generally act upon students in the lower end of the distribution of ability and/or desire to stay in school. Thus, the increased share of off-timers in the population of enrolled students at age 16-17 following the EL reform is arguably not surprising. Regrettably, our data contain information on test scores and academic performance only starting from 2008. However, Figure 7 shows that the date of birth is actually a strong determinant of the "off timer" status. In particular, juveniles born in

\footnotetext{
${ }^{26}$ Figure 6 shows that police criminal records and SDS records at the individual level exhibit the same strong positive correlation before and after the EL reform. This is reassuring, as it further suggests that the increase in violence SDS caused by the EL reform does not result from the increased propensity of schools to punish violence or from other unobserved confounding factors.
} 
the months prior to the $1^{\text {st }}$ January appear much more likely to be "off timers" than juveniles born after the $1^{\text {st }}$ January. This appears consistent with the existing literature on the negative consequences of early school eligibility on academic performance, since in Queensland the formal age at school start is in fact defined by the timing of birth. Administrative rules imply that children are expected to start grade one in the calendar year in which they turn six years old (QGOV, 2018b), and thus children born one day apart, i.e. December $31^{\text {st }}$ versus January $1^{\text {st }}$, are expected to start school one year apart. ${ }^{27}$ Even though there is some parental scope to deviate from the administrative rules governing school starting age of a child, children born either side of the $1^{\text {st }}$ January cut-off are subject to a one-year difference in timing of administratively determined school start. At a given $1^{\text {st }}$ January cut-off, children born in the final months of the prior calendar year (i.e., October-December) will likely start school one year earlier than their counterparts born in January-March of the following year.

In this final section, this institutional feature of the Queensland education system can be exploited to define early school eligible (ESE) juveniles, who are much more likely to be "off timers", and control juveniles, and compare their respective behavioural outcomes. This can be thought of as an Intention-To-Treat (ITT) analysis of the impact of compulsory schooling on the delinquent behaviour of "off timers" in and outside school. A regression discontinuity (RD) analysis is conducted here where ESE is modeled as a binary variable indicating whether youth $i$ was born in OctoberDecember (i.e., ESE $=1$ ) or in January-March (i.e., ESE $=0$ ), and the delinquent behaviour of these two groups of juveniles is compared. In contrast, juveniles born in the remainder of the calendar year are omitted from this analysis.

Formally, the OLS equation of interest for juvenile $i$ from day-month of birth $d$ in birth discontinuity $t$ can be expressed as follows:

\footnotetext{
27 A large literature shows that starting school at a younger age leads to a significant academic disadvantage from childhood and may alter the entire path of skill acquisition (Bedard and Dhuey, 2006; Datar, 2006; Puhani and Weber, 2007; Cunha and Heckman, 2008; McEwan and Shapiro, 2008; Elder and Lubotsky, 2009; Crawford, Dearden, and Meghir, 2010; Black, Devereux, and Salvanes, 2011; McCrary and Royer, 2011; and Fredriksson and Ockert, 2013). Recent literature also suggests that starting school at a younger age may place juveniles at a greater risk of committing crime (Cook and Kang, 2016; Depew and Eren, 2016; and Landersø, Nielsen and Simonsen, 2016), although none of the existing studies explicitly explore the link between school starting age and delinquent behaviour in school.
} 


$$
Y_{i d t}=\alpha+\gamma_{2} * E S E_{i d}+\gamma_{3} * D o b_{i d}+\gamma_{4} * D o b_{i d} * E S E_{i d}+\delta * X_{i}+\theta_{t}+u_{i d t},
$$

where $Y$ is the delinquent behaviour of juvenile $i$ from day-month of birth $d$ in discontinuity $t, E S E$ is defined as described above, $D o b$ is a continuous control for distance in birthday to the $1^{\text {st }}$ January cut-off, $\theta$ is a set of birth discontinuity fixed effects (i.e., indicator variables for being born in OctoberDecember 1987 - January-March 1988, October-December 1988 - January-March 1989, OctoberDecember 1989 - January-March 1990, etc.) and $u$ is the error term. $X$ is a vector of time-invariant individual characteristics which includes gender and native language of juvenile $i$.

Figure 8 shows the results of this RD analysis. The Figure reveals that ESE juveniles face a greater risk of committing criminal offences from age 18 up until age 20, when they are no longer subject to compulsory schooling laws. Prior to age 18, when they must attend school, ESE and control group juveniles are equally likely to commit crime. However, ESE juveniles appear more likely to receive SDS at age 16 and 17 . This crime-age profile is consistent with an incapacitation effect of school on crime, as schools exert a protective factor keeping ESE and "off time" juveniles away from crime up until they leave school. However, this crime-age profile also shows that schools internalise the bad behaviour of ESE and "off time" juveniles prior to them leaving school and gravitating towards crime. While arrested and incarcerated juveniles are significantly less likely to graduate from high school (Hjalmarsson, 2008) and significantly more likely to become recidivists either in youth or in adulthood (Mendel, 2011; Aizer and Doyle, 2015; Stevenson, 2017; Mueller-Smith and Schnepel, forthcoming), schools seem to internalise the bad behaviour of ESE juveniles and delay the onset of crime.

\section{Conclusion}

A large literature has documented the beneficial impact of compulsory school attendance, one of which is reduced crime. This has been a major driver of policy in the United States and elsewhere towards schooling and other youth intervention programmes aiming to support the path of human 
capital formation and labour market prospects, and discourage criminal participation of at-risk juveniles. However, little is known about the educational experience of juveniles when compulsory schooling laws are enacted to keep juveniles in school for longer. This is also due to the severe underreporting of delinquent behaviour in school to the police. Using administrative data linking education and criminal records at the individual level for all juveniles in the state school system in Queensland (Australia) from 2003 to 2013, this study examines the impact of a recent minimum dropout age (MDA) reform on the educational experience of juveniles and its effect on their criminal trajectories.

The "Earning or Learning” (EL) reform raised the MDA from 16 to 17 in Queensland on the $1^{\text {st }}$ January 2006, and a series of regression-discontinuity (RD) estimates are derived to estimate its impact on the dropout behaviour and delinquency in school of juveniles exposed to this reform. Juveniles directly exposed to the reform spent longer time in school and experienced a significant and lasting reduction in their propensity to commit property and drugs criminal offences. However, school records also suggest that the same juveniles were more likely to display violent behaviour in school at age 16-17. These findings are consistent both with an incapacitation effect of school on property and drugs crime, and with a concentration effect of school on violence. These conclusions appear robust to the set of controls included in the estimated equation, to estimation method and alternative plausible sampling restrictions. A placebo test where the EL reform is artificially moved back by one year-of-birth cohort confirms our causal interpretation of these findings.

A series of statistical tests suggests that the increase in in-school violence is not the result of the increased propensity of schools to punish, nor the result of modified school resources, school principals or any other school-specific idiosyncratic shock. Our results unveil a genuine increase in violence on the school premises that is not compensated by any reduction in violence in the police records, and that is plausibly the result of the greater share of males, native speakers, "off-timers" and low socio-economic background juveniles in the population of students enrolled at age 16-17. Building on the literature on the academic disadvantage caused by early school eligibility, evidence 
is also presented that schools internalise the delinquent behaviour of low performers and "off timers", as proxied by early school eligible students.

The main contribution of this study is a recognition that schools internalize violent juvenile behaviour, and much of the crime reduction generated by an increase in compulsory schooling appears to be at least in part offset by an increase in violence on school premises. As police records do not fully account for all student victimization and all known youth crime, prior literature which omits consideration of in-school discipline records may overestimate the magnitude of the crimereducing effect, and hence the desirability, of MDA laws in the short run. The EL policy experiment, combined with our data, provides a rare opportunity to assess the effectiveness of modern MDA reforms in reducing youth crime both in and outside of school. From the perspective of a policy maker designing a policy that would alter the dropout behaviour of the general population of youth, the parameter estimated here is directly of interest.

From a policy perspective, this study highlights the need to supplement youth justice policies and MDA law changes with services that help keep students interested and engaged in learning and prevent the potential increase in school violence documented here. Modern compulsory schooling laws must go beyond fines and other sanctions for school absenteeism and must include effective approaches to combat disengagement and help students stay in school out of choice, even when dropping out is permitted. If an adolescent at risk is forced to stay at school, this in part shifts trouble from outside to inside the school premises, and the school system needs appropriate support to be most effective in reducing crime. Generating an understanding of the education experience of adolescents at risk and their delinquent behaviour in school is a first step toward helping them avoid the revolving door between poor school behaviour, juvenile delinquency and future incarceration. 


\section{References}

Acemoglu, D., and Angrist, J. D. (2001). How Large Are Human-Capital Externalities? Evidence from Compulsory Schooling Laws, in Ben S. Bernanke and Kenneth, eds., Rogoff, NBER Macroeconomics Annual 2000. Cambridge, MA: MIT Press, pp. 9-59.

Albouy, V., and Lequien, L. (2009). Does Compulsory Education Lower Mortality? Journal of Health Economics 28 (1): 155-68.

Aizer, A. (2008). Neighborhood Violence and Urban Youth. NBER Working Paper Series, National Bureau of Economic Research, 2008, 13773 (13773).

Aizer, A., and Doyle, J. J. Jr. (2015). Juvenile Incarceration, Human Capital and Future Crime: Evidence from Randomly-Assigned Judges. Quarterly Journal of Economics 130, 759-803.

Anderson, D. (2014). In School and Out of Trouble? The Minimum Dropout Age and Juvenile Crime, Review of Economics and Statistics, 96, 318-31.

Anderson, D., Hansen, B. and Walker, M. B. (2013). The minimum dropout age and student victimization. Economics of Education Review 35: 66-74.

Ang, D. (2020). The Effects of Police Violence on Inner-City Students. HKS Faculty Research Working Paper Series RWP20-016, June 2020.

Angrist, J. D., and Krueger, A. B. (1991). Does Compulsory School Attendance Affect Schooling and Earnings? Quarterly Journal of Economics, 106(4), pp. 979-1014.

Australian Bureau of Statistics. (2003). Australian Social Trends 2003. Australian Bureau of Statistics. Australian Government. Available online at the following link: http://www.abs.gov.au/AUSSTATS/abs@.nsf/allprimarymainfeatures/2356424C275E3E45 CA256EB400035395?opendocument, accessed 30 July, 2020.

Australian Bureau of Statistics (2017). Recorded Crime - Offenders for the year 2015-16. Available at: $\quad$ http://www.abs.gov.au/ausstats/abs@.nsf/Lookup/by\%20Subject/4519.0 201516 Main\%20Features $\sim$ Youth\%20offenders 4

Bacher-Hicks, A., Billings, S. and Deming, D. (2019). The School to Prison Pipeline: Long-Run Impacts of School Suspensions on Adult Crime, National Bureau of Economic Research Working Paper No. 26257 (September 2019).

Beatton, D., Kidd, M., Machin, S.J. and Sarkar, D. (2018). Larrikin Youth: Crime and Queensland's Earning and Learning Reform. Labour Economics, 52, 149-159.

Bedard, K. and Dhuey, E. (2006). The Persistence of Early Childhood Maturity International Evidence of Long-Run Age Effects. Quarterly Journal of Economics, 121, 1437-1472.

Bell, B., Costa, R. and Machin, S. (2016). "Crime, Compulsory Schooling Laws and Education", Economics of Education Review, 54, 214-26.

Bell, B., Costa, R. and Machin, S. (2018). "Why Does Education Reduce Crime?”, IZA Discussion Paper No. 11805. 
Billings, S., Deming, D. and Rockoff, J. (2014). School segregation, educational attainment, and crime: evidence from the end of busing in Charlotte-Mecklenburg, Quarterly Journal of Economics 129, 435-476.

Billings, S. B. and Hoekstra, M. (2018). Schools, Neighborhoods, and the Long-Run Effect of CrimeProne Peers. Unpublished working paper.

Bindler, A., Hjalmarsson, R. and Ketel, N. (2020). Costs of Victimization. In: Klaus Zimmermann (eds) Handbook of Labor, Human Resources and Population Economics. Springer, Cham.

Black, S., Devereux P. and Salvanes, K. (2011). Too young to leave the nest? The effects of school starting age. Review of Economics and Statistics; 93 (2): 455-467.

Brown, R. and Velasquez A. (2017). The effect of violent crime on the human capital accumulation of young adults. Journal of Development Economics, 2017, 127 (January), 1-12.

Bruck, T., Di Maio, M. and Miaari, S. (2019). Learning The Hard Way: The Effect of Violent Conflict on Student Academic Achievement. Journal of the European Economic Association, 2019, 0 (0), 1-36.

Buscha, F. and Dickson, M. (2012). The raising of the school leaving age: returns in later life. Economics Letters, vol. 117 (2), pp. 389-393.

Cano-Urbina, J., and Lochner, L. (2019). The effect of education and school quality on female crime. Journal of Human Capital, 2019, 13.2: 188-235.

Card, D. (1995). Using Geographic Variation in College Proximity to Estimate the Return to Schooling, in Louis N. Christofides, E. Kenneth Grant, and Robert Swidinsky, eds., Aspects of labour market behaviour: Essays in honour of John Vanderkamp. Toronto: University of Toronto Press, pp. 201-22.

Card, D. (1999). The Causal Effect of Education on Earnings. In Handbook of Labor Economics, Vol. 3A, edited by Orley Ashenfelter and David Card, 1801-63. Amsterdam: Elsevier.

Carneiro, P., Heckman, J. J., and Vytlacil, E. J. (2011). Estimating Marginal Returns to Education. American Economic Review 101 (October 2011): 2754-2781.

Carrell, S., and Hoekstra, M. (2010). Externalities in the classroom: How children exposed to domestic violence affect everyone's kids. American Economic Journal: Applied Economics, 2(1), 211-228.

Carrell, S. E., Hoekstra, M. and Kuka, E. (2018). The Long-Run Effects of Disruptive Peers. American Economic Review, 108 (11): 3377-3415.

Carrell, S., Malmstrom, F. and West, J. (2008). Peer effects in academic cheating. Journal of Human Resources, 43(1), 173-207.

Carreras, E., Gibbons, M.A., Murphy, T.E., Perez-Vincent, S.M. and Rossi. (2020). COVID-19 Lockdowns and Domestic Violence: Evidence from Two Studies in Argentina. IDB Technical Note No. IDB-TN-1956. 
Cook, P.J. and Kang, S. (2016). Birthdays, Schooling, and Crime: Regression-Discontinuity Analysis of School Performance, Delinquency, Dropout, and Crime Initiation. American Economic Journal: Applied Economics, 8(1): 33-57

Cooley-Quille, M., Turner, S. and Beidel D. (1995). Emotional impact of children's exposure to community violence: a preliminary study. Journal of the American Academy of Child and Adolescent Psychiatry, oct 1995, 34 (10), 1362-8.

Cornaglia F., Feldman, N.E. and Leigh, A. (2014). Crime and mental well-being. Journal of Human Resources, 49(1):110-140.

Crawford, C., Dearden, L. and Meghir, C. (2010). When you are born matters: the impact of date of birth on educational outcomes in England. Working Paper 10/06. London: Institute for Fiscal Studies.

Cunha, F. and Heckman, J. (2008). Formulating, Identifying and Estimating the Technology of Cognitive and Noncognitive Skill Formation. Journal of Human Resources, 43, 738-782.

Damm, A. P., and Dustmann, C. (2014). Does growing up in a high crime neighborhood affect youth criminal behavior? American Economic Review, 104(6):1806-32.

Datar, A. (2006). Does delaying kindergarten entrance give children a head start? Economics of Education Review, 25, 43-62.

Del Bono, E., and Galindo-Rueda, F. (2007). The Long Term Impacts of Compulsory Schooling: Evidence from a Natural Experiment in School Leaving Dates. CEE Discussion Papers 0074, Centre for the Economics of Education, LSE.

Deming, D. (2011). Better schools, less crime? Quarterly Journal of Economics 126, 2063-2115.

Depew, B. and Eren, O. (2016). Born on the wrong day? School entry age and juvenile crime. Journal of Urban Economics, vol. 96, November 2016, pp. 73-90.

Devereux, P. J., and Hart, R. A. (2010). Forced to Be Rich? Returns to Compulsory Schooling in Britain. The Economic Journal 120 (549): 1345-64.

Dickson, M. (2013). The causal effect of education on wages revisited. Oxford Bulletin of Economics and Statistics, vol. 75 (4), pp. 477-498.

Dickson, M., and Smith, S. (2011). What determines the return to education: an extra year or a hurdle cleared? Economics of Education Review, vol. 30 (6), pp. 1167-1176.

Domnisoru, C. (2015). The Secular Decline in Teen Employment: The Role of Compulsory Schooling and Work Permits. Carnegie Mellon University April 2015.

Elder, T.E. and Lubotsky, D.H. (2009). Kindergarten entrance age and children's achievement: impacts of state policies, family background, and peers. Journal of Human Resources, vol. 44(3), pp. 641-83 
Fella, G. and Gallipoli, G. (2014). Education and Crime over the Life Cycle. The Review of Economic Studies, Volume 81, Issue 4, October 2014, Pages 1484-1517, https://doi.org/10.1093/restud/rdu014

Figlio, D. (2007). Boys named sue: Disruptive children and their peers. Education Finance and Policy, 2(4), 376-394.

Fowler, P., Tompsett, C., Braciszewski, J., Jacques-Tiura, A. and Baltes, B. (2009). Community violence: a meta-analysis on the effect of exposure and mental health outcomes of children and adolescents. Development and psychopathology, Jan 2009, 21 (1), 227-59.

Fredriksson, P. and Ockert, B. (2013). Life-cycle effects of age at school start. The Economic Journal, September 2013, 124, 977-1004.

Gaviria, A., and Raphael, S. (2001). School-based peer effects and juvenile behavior. Review of Economics and Statistics, 83(2), 257-268.

Gilpin, G. A. and Pennig, L. A. (2015). Compulsory schooling laws and school crime. Applied Economics, 47:38, 4056-4073, DOI: 10.1080/00036846.2015.1023944

Grenet, J. (2013). Is Extending Compulsory Schooling Alone Enough to Raise Earnings? Evidence from French and British Compulsory Schooling Laws. The Scandinavian Journal of Economics 115 (1): 176-210.

Grogger, J. (1997). Local violence and educational attainment. Journal of Human Resources, 32(4), $659-682$.

Harmon, C., and Walker, I. (1995). Estimates of the Economic Return to Schooling for the United Kingdom. American Economic Review, 85(5), pp. 1278-86.

Heller, S. (2014). Summer jobs reduce violence among disadvantaged youth. Science 346, 12191223.

Heller, S., Shah, A., Guryan, J., Mullainathan, S. and Pollack, H. (2017). Thinking fast and slow? Some field experiments to reduce crime and dropout in Chicago. Quarterly Journal of Economics 132, 1-53.

Hjalmarsson, R. (2008). Criminal justice involvement and high school completion. Journal of Urban Economics, 63, 613-30. doi:10.1016/j.jue.2007.04.003

Hjalmarsson, R., Holmlund, H., and Lindquist, M. (2015). The Effect of Education on Criminal Convictions and Incarceration: Causal Evidence from Micro-Data. Economic Journal, 125, 1290-1326.

Jacob, B. and Lefgren, L. (2003). Are Idle Hands the Devil's Workshop? Incapacitation, Concentration and Juvenile Crime. American Economic Review, 93, 1560-77.

Jeffrey, T. (2012). 1,183,700 Violent Crimes Committed at Public Schools; Only 303,900 Reported to Police. CNS News. Available at: http://cnsnews.com/news/article/1183700-violent-crimescommitted-public-schools-only-303900-reported-police. 
Kawaguchi, D. (2004). Peer effects on substance use among American teenagers. Journal of Population Economics, 17(2), 351-367.

Kinsler, J. (2013). School discipline: A source or salve for the racial achievement gap? International Economic Review, 54(1), 355-383.

Kling, J. R. (2001). Interpreting Instrumental Variables Estimates of the Returns to Schooling. Journal of Business and Economic Statistics, 19(3): 358-64.

Koop, G., and Tobias, J. L. (2004). Learning about heterogeneity in returns to schooling. Journal of Applied Econometrics, vol.19: pp. 827-849.

Koppensteiner, M. F. and L. Menezes. (forthcoming). Violence and human capital investments. Journal of Labor Economics (forthcoming).

Landersø., R., Nielsen., H.S. and Simonsen, M. (2016). School Starting Age and the Crime-Age Profile. The Economic Journal, 127, 1096-1118.

Lazear, E. P. (2001). Educational production, Quarterly Journal of Economics, 116, 777-803.

Leigh, A. (2008). Returns To Education In Australia. Economic Papers Vol. 27 No. 3 September 2008 pp. 233-249.

Leslie, E., and R. Wilson. (forthcoming). Sheltering in Place and Domestic Violence: Evidence from Calls for Service during COVID-19. Journal of Public Economics. Available at: https://papers.ssrn.com/sol3/papers.cfm?abstract_id=3600646

Lleras-Muney, A. (2005). The Relationships Between Education and Adult Mortality in the United States. Review of Economic Studies 72 (250): 189-221.

Lochner, L. (2020). Education and crime. The Economics of Education. Academic Press, 2020. p. 109-117.

Lochner, L. and Moretti, E. (2004). The Effect of Education on Crime: Evidence from Prison Inmates, Arrests and Self-Reports. American Economic Review, 94, 155-89.

Luallen, J. (2006). School's Out... Forever: A Study of Juvenile Crime, At-Risk Youths and Teacher Strikes. Journal of Urban Economics, 59:75.

Lundborg, P. (2006). Having the wrong friends? Peer effects in adolescent substance use. Journal of Health Economics, 25(2), 214-233.

Machin, S., Marie, O. and Vujic, S. (2011). The Crime Reducing Effect of Education. The Economic Journal, 121, 463-84.

Machin, S., and Meghir, C. (2004). Crime and Economic Incentives. Journal of Human Resources 39(4): 958-79.

McCrary, J., and Royer, H. (2011). The Effect of Female Education on Fertility and Infant Health: Evidence from School Entry Policies Using Exact Date of Birth. American Economic Review, 101(1): 158-95. 
McCrary, J., and Sanga, S. (2020). The Impact of the Coronavirus Lockdown on Domestic Violence. Available at SSRN 3612491.

McEwan, P. J., and Shapiro, J. S. (2008). The benefits of delayed primary school enrolment: Discontinuity evidence using exact birth dates. Journal of Human Resources, 43(1), 1-29.

Meghir, C., Palme, M. and Schnabel, M. (2012). The effect of education policy on crime: an intergenerational perspective, NBER Working paper No. 18145.

Mendel, R. A. (2011). No Place for Kids: The Case for Reducing Juvenile Incarceration. Annie E. Casey Foundation Technical Report.

Messacar, D., and Oreopoulos, P. (2012). Staying in School: A Proposal to Raise High School Graduation Rates; Discussion Paper No. 2012-07; The Hamilton Project; Brookings Institution: Washington, DC, USA, 2012; Available online: https://www.hamiltonproject.org/assets/files/a_proposal_to_raise_high_school_graduation_r ates.pdf (accessed on 24 August 2020).

Monteiro, J., and Rocha, R. (2017). Drug Battles and School Achievement: Evidence from Rio de Janeiro's Favelas. Review of Economics and Statistics, 2017, 99 (2), 213-228.

Mueller-Smith, M., and Schnepel, K. T. (Forthcoming). Diversion in the Criminal Justice System. The Review of Economic Studies, Forthcoming.

Murphy, R. and Weinhardt, F. (2018). Top of the class: The importance of ordinal rank, National Bureau of Economic Research Working Paper No. 24958.

Oreopoulos, P. (2006). Estimating Average and Local Average Treatment Effects of Education when Compulsory Schooling Laws Really Matter. American Economic Review 96 (1): 152-75.

Oreopoulos, P. (2009). Would more compulsory schooling help disadvantaged youth? Evidence from recent changes to school- leaving laws. In: Gruber, J. (Ed.), The Problems of Disadvantaged Youth: An Economic Perspective, National Bureau of Economic Re- search. University of Chicago Press.

Pischke, J.-S. and von Wachter, T. (2008). Zero Returns to Compulsory Schooling in Germany: Evidence and Interpretation, Review of Economics and Statistics 90 (2008), 592-598.

Powell, L., Tauras, J., and Ross, H. (2005). The importance of peer effects, cigarette prices, and tobacco control policies for youth smoking behavior. Journal of Health Economics, 24(5), 950-968.

Puhani, P. A. and Weber, A. M. (2007). Persistence of the School Entry Age Effect in a System of Flexible Tracking. IZA Discussion Paper No. 2965; University of St. Gallen Economics Discussion Paper No. 2007-30.

QGOV (2018a). Queensland School System. Queensland State Government. https://www.qld.gov.au/education/international/qualifications/school/pages/system, accessed 30 January, 2018. 
QGOV (2018b). Enrolment age requirements. Queensland State Government. https://www.qld.gov.au/education/schools/find/enrolment/pages/age, accessed 30 January, 2018

QGOV (2018c). Strengthening discipline in Queensland state schools. Queensland State Government. http://education.qld.gov.au/schools/strengthening-discipline/, accessed 30 January, 2018.

Quetelet, A. (1831) [1984]. Research on the Propensity for Crime at Different Ages, translated and introduced by Sawyer F. Sylvester. Cincinnati: Anderson

Rivkin, S. G., and Schiman, J. C. (2015). Instruction Time, Classroom Quality, and Academic Achievement. The Economic Journal, 125(588).

Robertson, D., and Symons, J. (2003). Do peer groups matter? Peer group versus schooling effects on academic attainment. Economica, 70(277), 31-53.

Sharkey, P., Schwartz, A. E., Gould Ellen, I., Lacoe, J. Sørensen, J. and Morgan, S. (2014). High Stakes in the Classroom, High Stakes on the Street: The Effects of Community Violence on Students' Standardized Test Performance. Sociological Science, 2014, 1, 199-220.

Smith, D. and Tolan, P. (1998). The role of exposure to community violence and developmental problems among inner-city youth. Development and Psychopathology, 1998, 10, 101-116.

Stevenson, M. (2017). Breaking Bad: Mechanisms of Social Influence and the Path to Criminality in Juvenile Jails. The Review of Economics and Statistics, December 2017, 99(5): 824-838

Trump, K. (2012). School Crime Reporting and School Crime Underreporting. National School Safety and Security Services. Available at:

http://www.schoolsecurity.org/trends/school_crime_reporting.html. 
Figure 1. Correlation between Crime and School Discipline Sanctions (SDS)

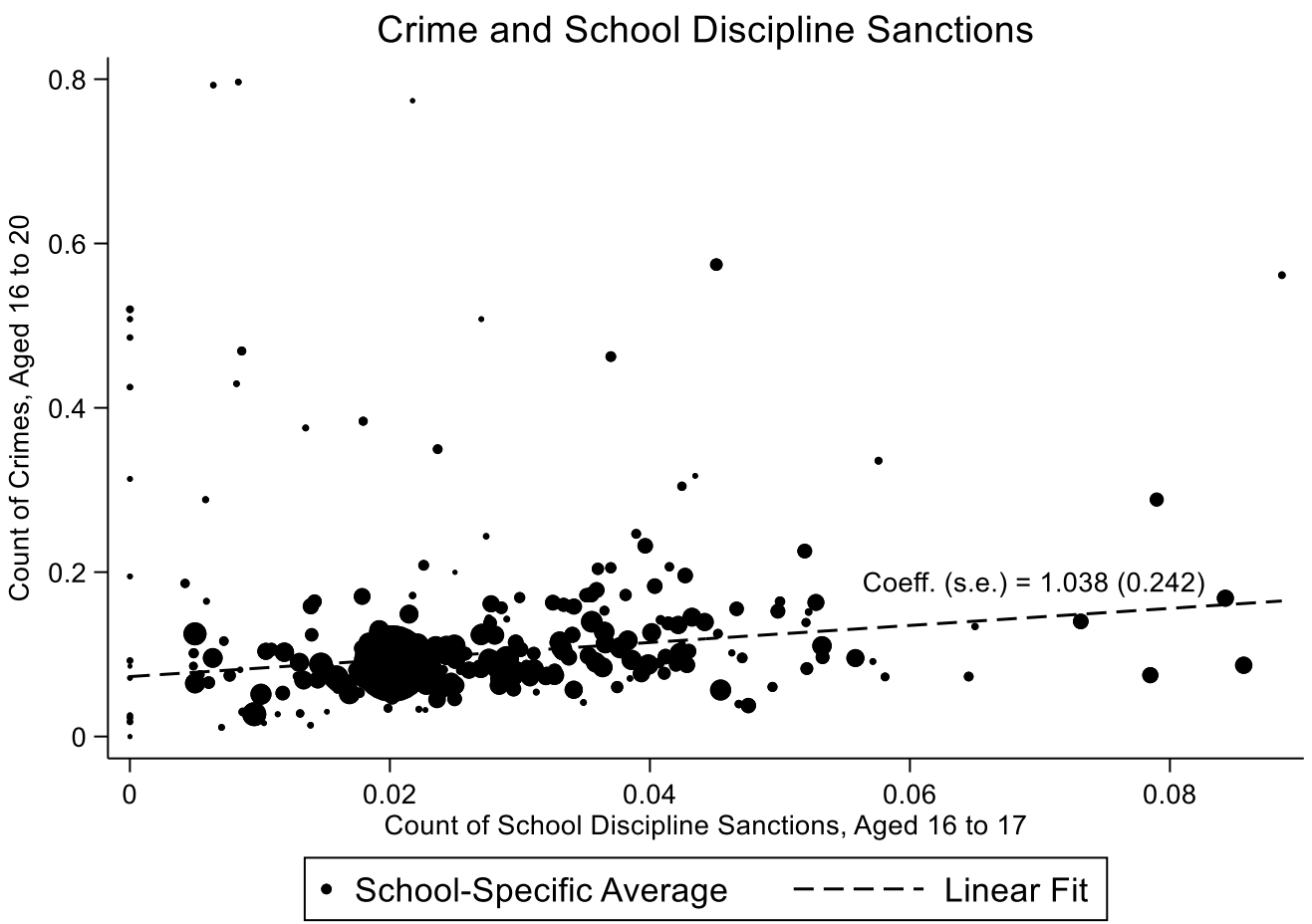

Notes: Figure shows for each school the average number of crime offences per individual at age 16-20 plotted against the average number of School Discipline Sanctions (SDS) at age 16-17. Crime offences include property damage and theft, drugs and violence by offender in a year. Violence includes violence against the person, sexual offences, and public order offences by offender in a year. SDS include property misconduct SDS, illicit substance SDS and violent SDS received per youth in a year. 
Figure 2. Descriptive Determinants of Crime and School Discipline Sanctions (SDS)

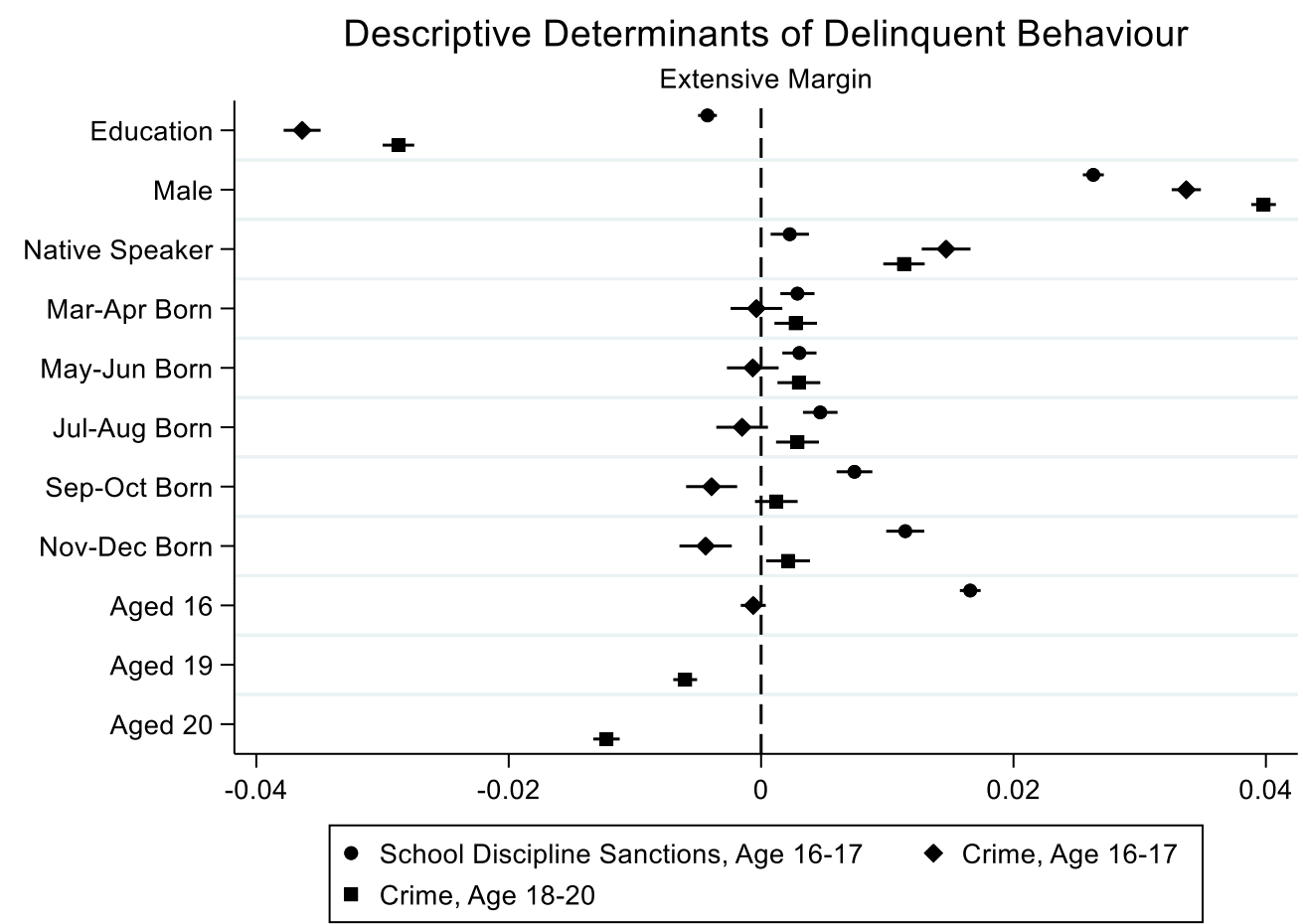

Notes: Figure shows point estimates and 95 percent confidence intervals of the determinants of crime offences (extensive margin) and school discipline sanction (SDS, extensive margin). All estimates are obtained from OLS regression specifications which include school year fixed effects. Standard errors are clustered at the individual level. Crime offences include property damage and theft, drugs and violence by offender in a year. Violence includes violence against the person, sexual offences, and public order offences by offender in a year. SDS include property misconduct SDS, illicit substance SDS and violent SDS received per youth in a year. 
Figure 3. Earning or Learning (EL) Reform and Dropout Grade

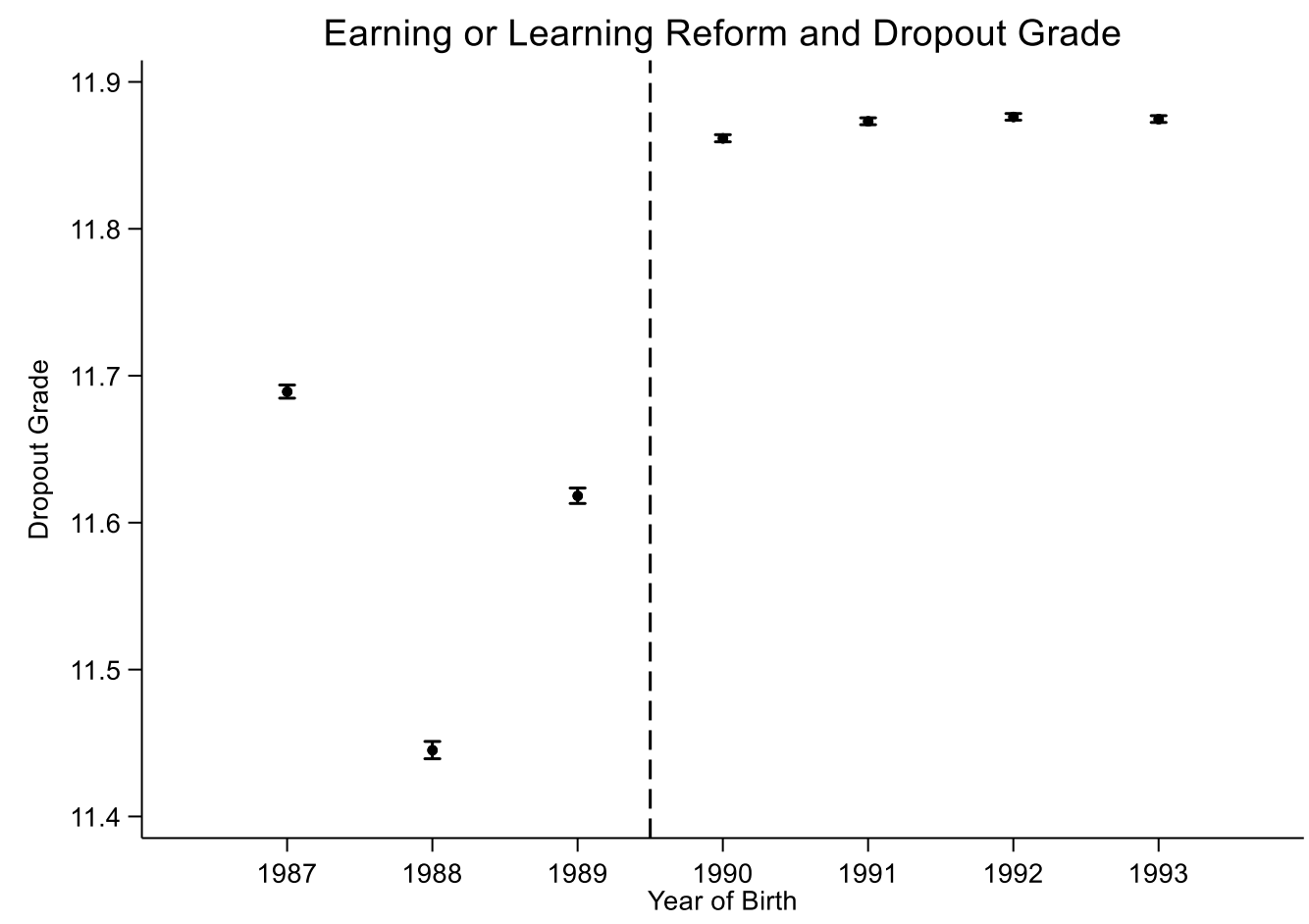

Notes: Figure shows unconditional point estimates from raw data and 95 percent confidence intervals of the average dropout grade by year of birth for the entire sample in the analysis. Dropout grade defined as the highest grade in which an individual is observed to be enrolled in statemaintained schools in Queensland. 
Figure 4. Earning or Learning (EL) Reform and School Discipline Sanctions (SDS)

\section{Panel A}

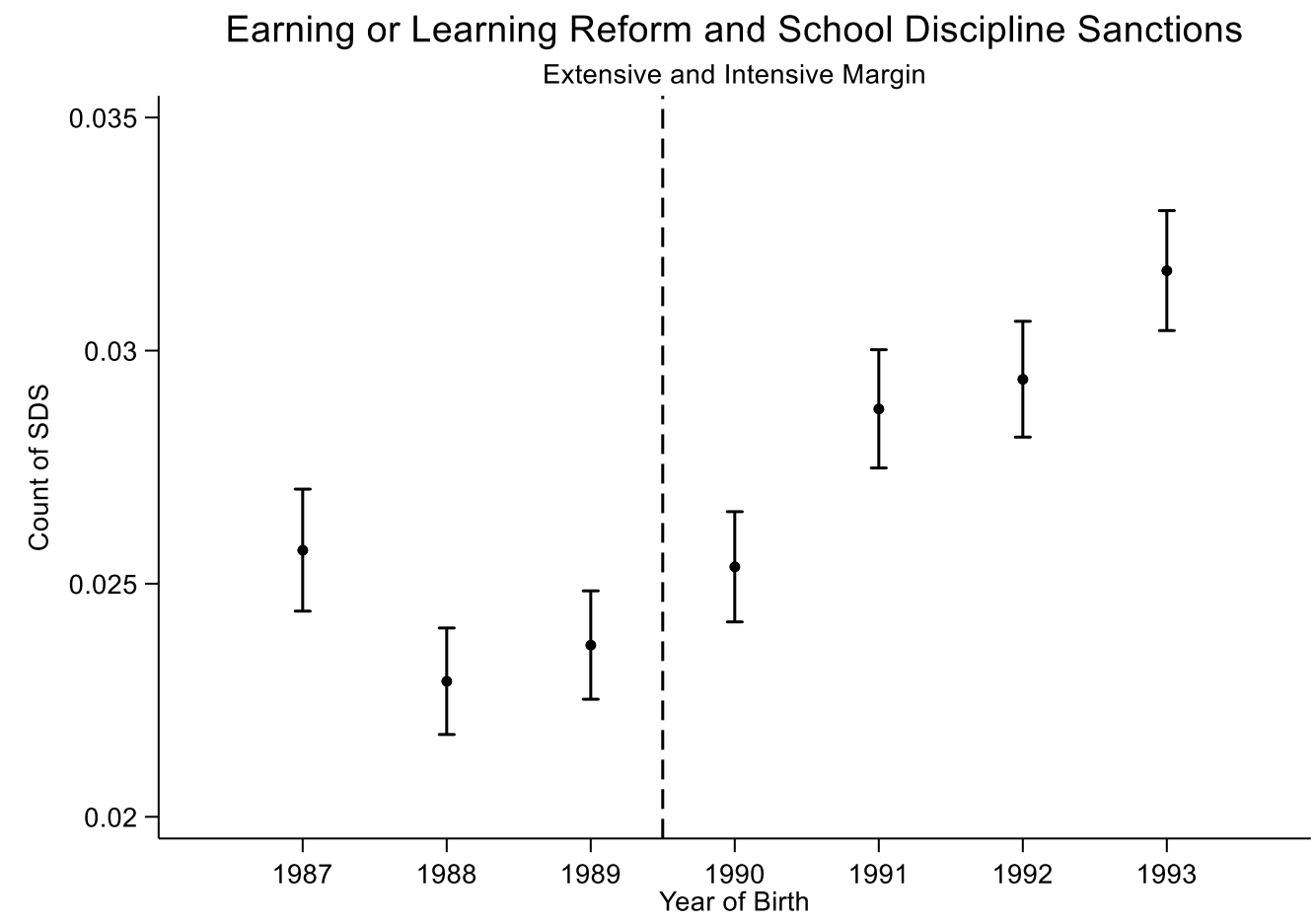

\section{Panel B}

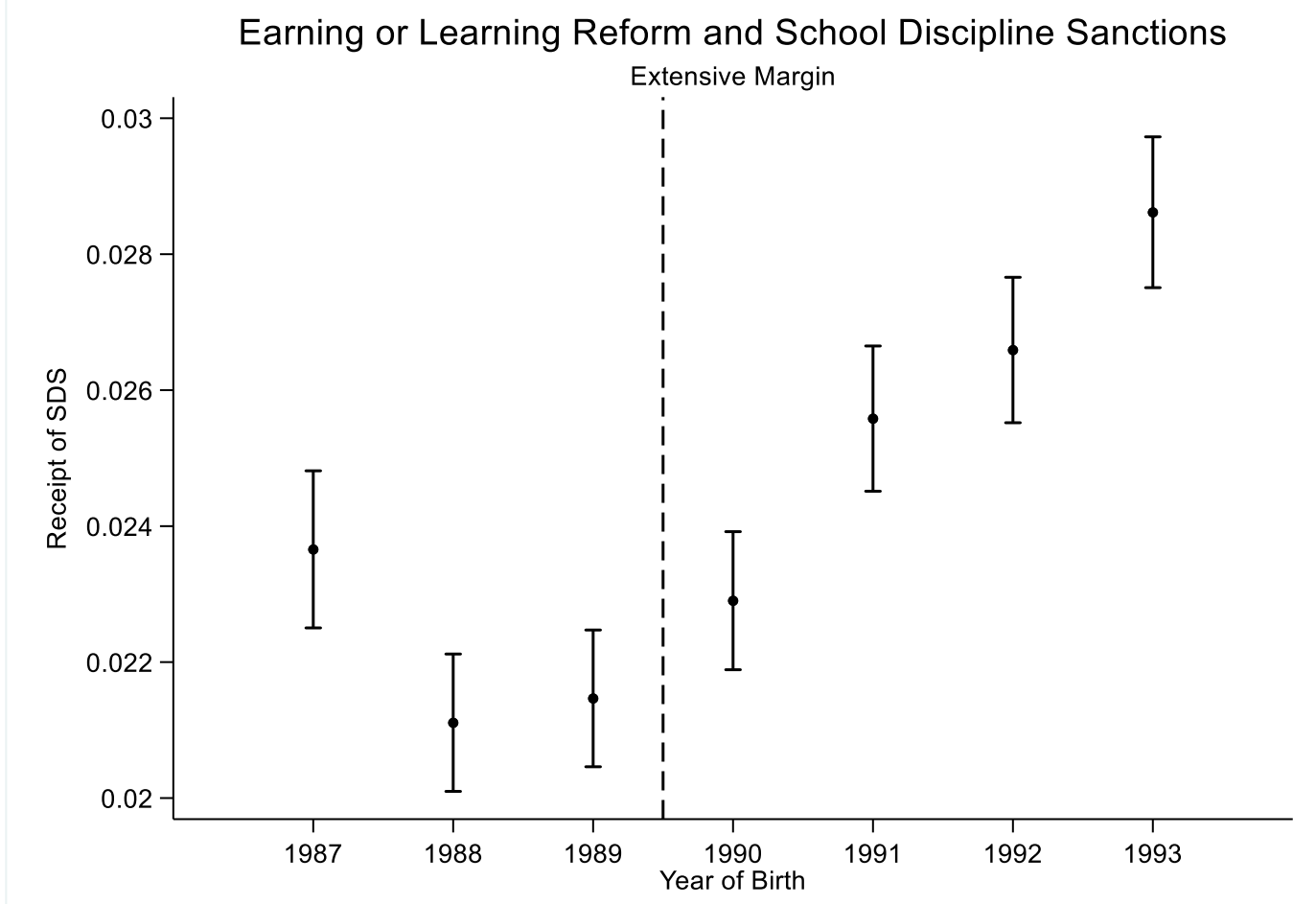

Notes: Figure shows unconditional point estimates from raw data and 95 percent confidence intervals of the average count of School Discipline Sanctions (SDS) per individual at age 16-17 by year of birth (Panel A) and the average likelihood to receive SDS at age 16-17 by year of birth (Panel B). SDS include property misconduct SDS, illicit substance SDS and violent SDS received per youth in a year. 
Figure 5. Earning or Learning (EL) Reform and Violent School Discipline Sanctions (SDS)

\section{Panel A}

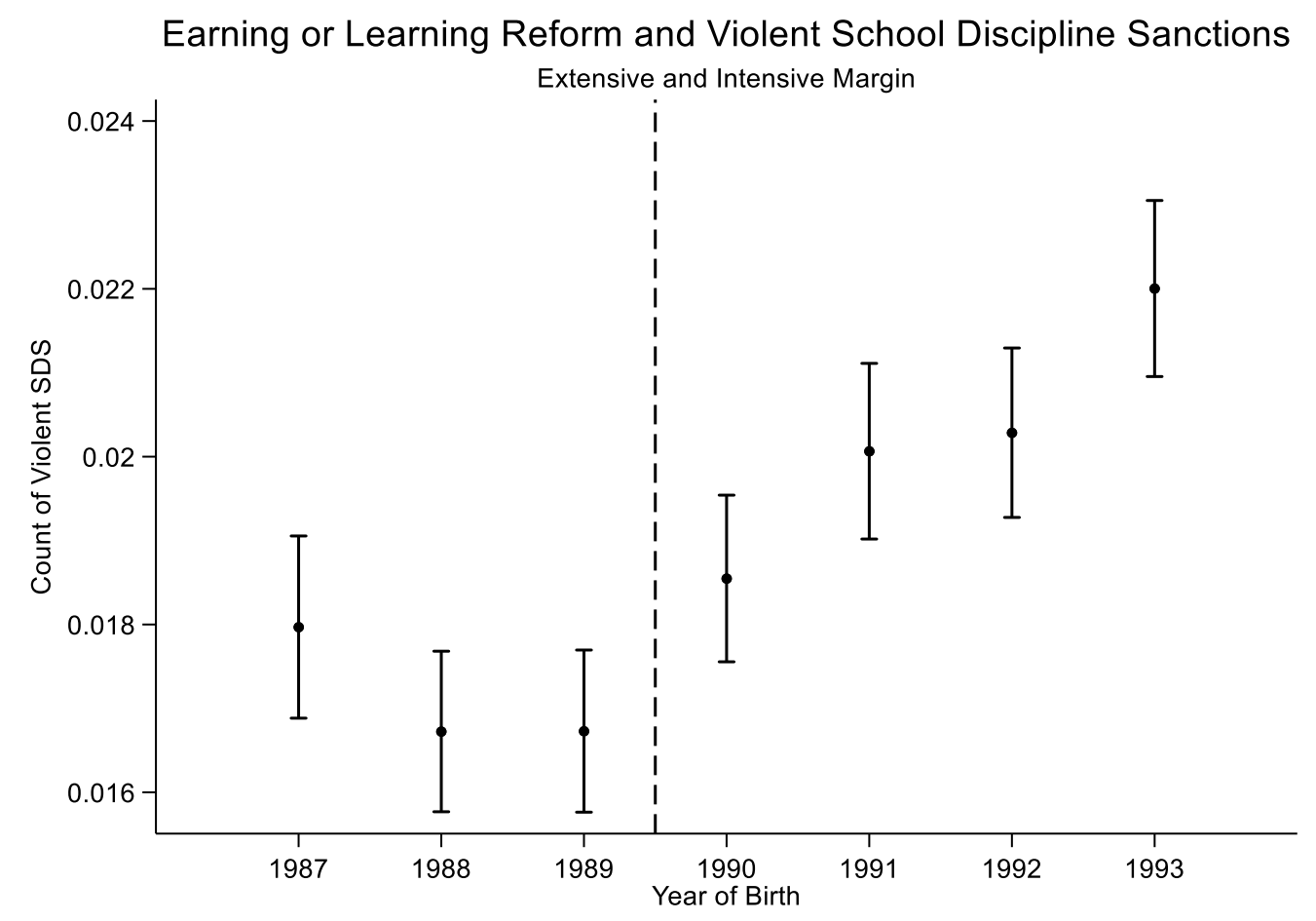

\section{Panel B}

Earning or Learning Reform and Violent School Discipline Sanctions

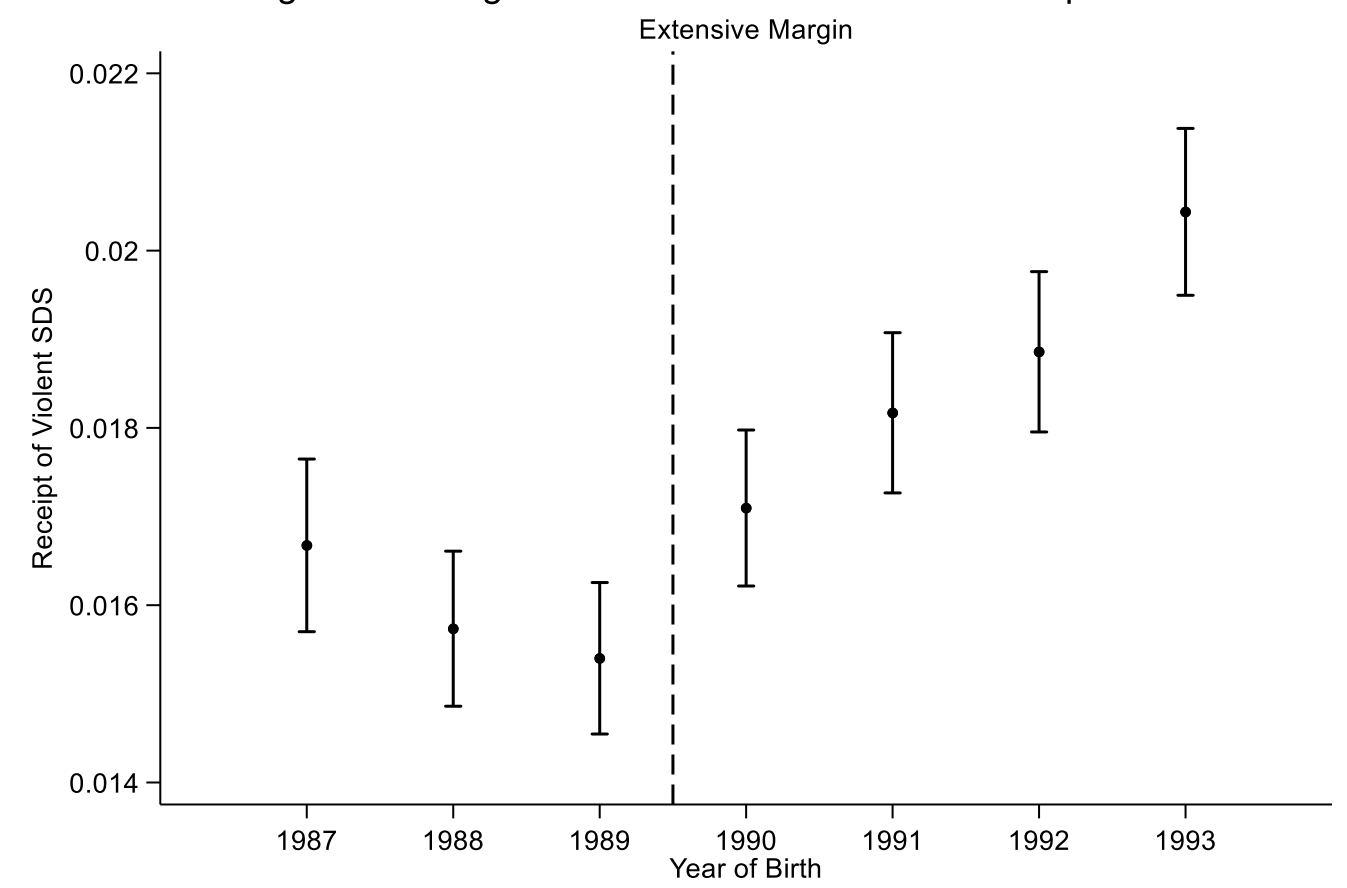

Notes: Figure shows unconditional point estimates from raw data and 95 percent confidence intervals of the average count of violent School Discipline Sanctions (SDS) per individual at age 16-17 by year of birth (Panel A) and the average likelihood to receive violent SDS at age 16-17 by year of birth (Panel B). 


\section{Figure 6. Correlation between School Discipline Sanctions (SDS) and Crime Before and After the Earning or Learning (EL) Reform}

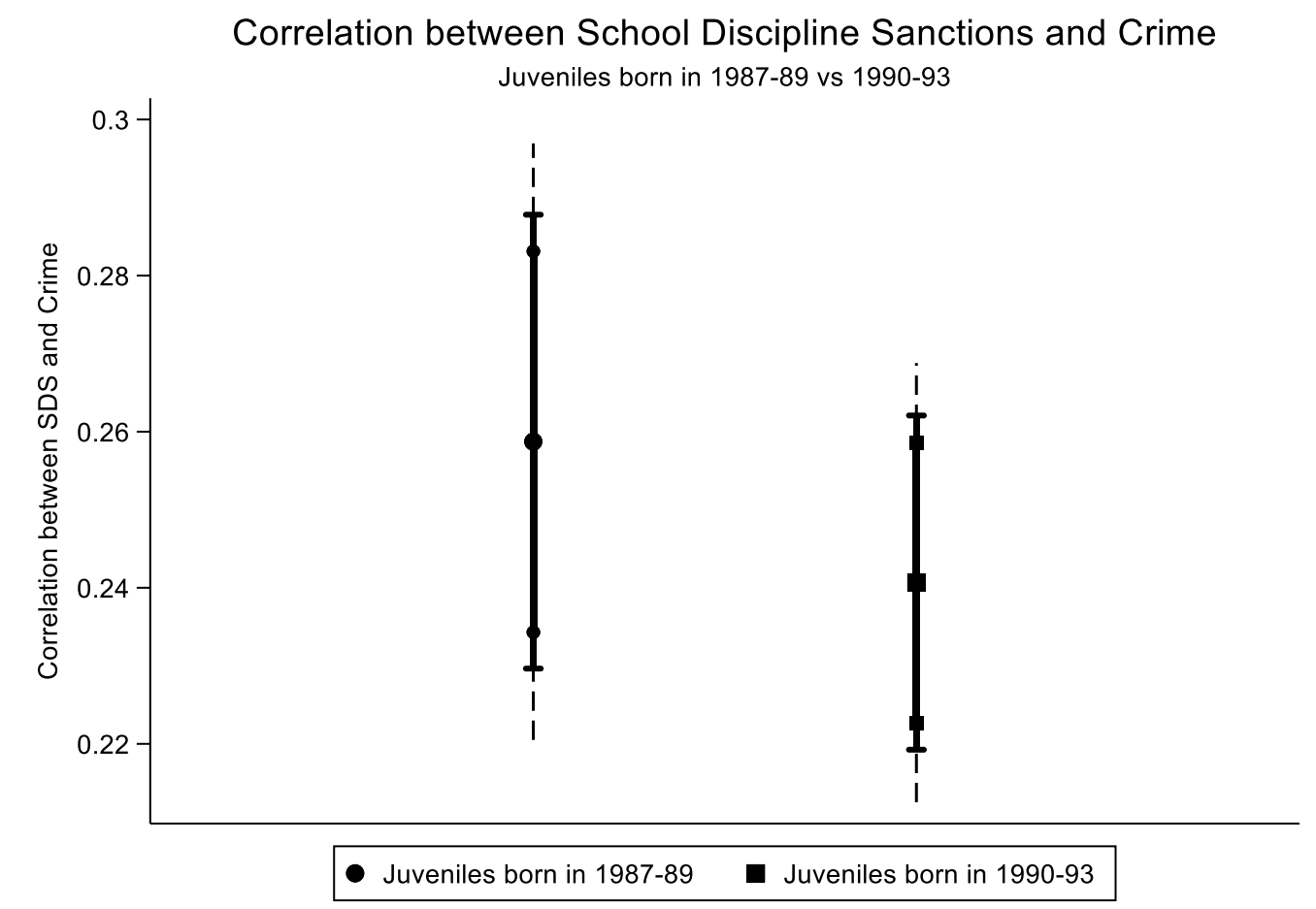

Notes: Figure shows the correlation between the number of crime offences per individual at age 16-20 and the number of School Discipline Sanctions (SDS) per individual at age 16-17 separately for individuals born from 1987-89 and from 1990-93. Crime offences include property damage and theft, drugs and violence by offender in a year. Violence includes violence against the person, sexual offences, and public order offences by offender in a year. SDS include property misconduct SDS, illicit substance SDS and violent SDS received per youth in a year. 
Figure 7. Impact of Early School Eligibility on "Off Time" Status

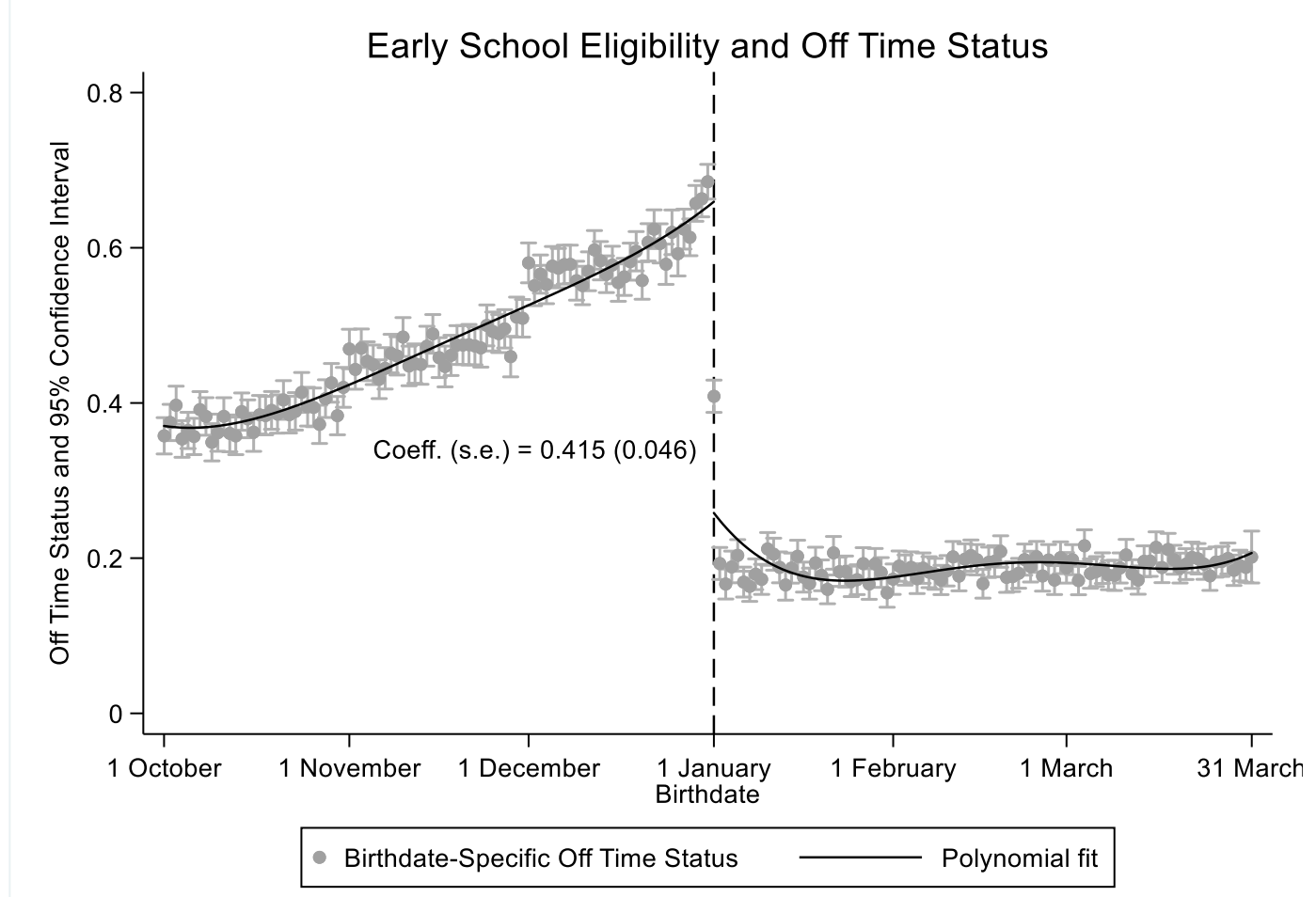

Notes: Figure shows point estimates and 95 percent confidence intervals of the causal effect of early school eligibility (ESE) on the likelihood to be off time in school. Off time students defined as students not attending grade 10 at age 15, i.e., the expected school grade based on year of birth prior to reaching the school leaving age. All estimates are obtained from OLS regression specifications on individuals born from $1^{\text {st }}$ October to $31^{\text {st }}$ March, i.e., within three months either side of the $1^{\text {st }}$ January cut-off. All specifications include distance to the $1^{\text {st }}$ January cut-off, pre-cutoff indicator (Nov-Dec $=1$ ) and their interaction term. Robust standard errors were clustered at the date of birth level. 


\title{
Figure 8. School Discipline Sanctions-Age (SDS-Age) and Crime-Age Profiles of Early School Eligible Youth
}

\author{
Count of Crimes or School Discipline Sanctions
}

(Extensive and Intensive Margin)

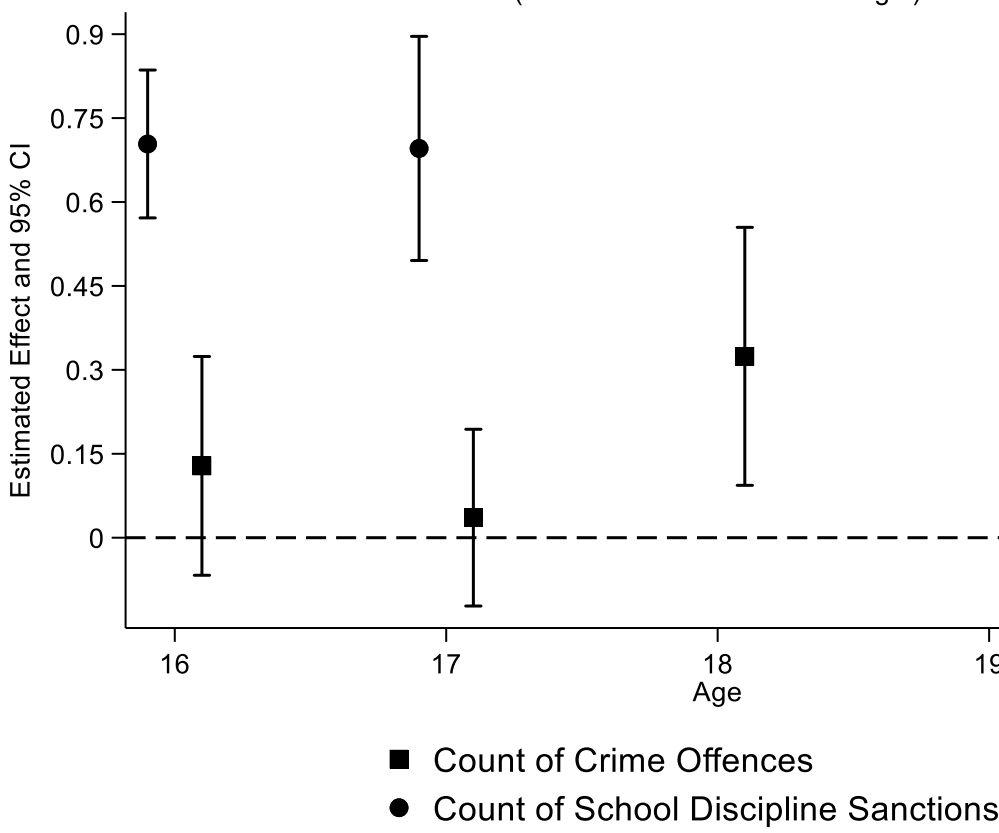

Notes: Figure shows point estimates and 95 percent confidence intervals of the causal effect of early school eligibility (ESE) on the count of crimes and school discipline sanctions (SDS) by age. All estimates are obtained from OLS regression specifications on individuals born from $1^{\text {st }}$ October to $31^{\text {st }}$ March, i.e., within three months either side of the $1^{\text {st }}$ January cut-off. All specifications include distance to the $1^{\text {st }}$ January cut-off, pre-cut-off indicator $($ Nov-Dec $=1)$, their interaction term, school fixed effects and discontinuity fixed effects. Robust standard errors were clustered at the date of birth level. Control variables included are dummies for whether the youths are male and whether they are native English speakers. Crime offences include property damage and theft, drugs and violence by offender in a year. Violence includes violence against the person, sexual offences, and public order offences by offender in a year. SDS include property misconduct SDS, illicit substance SDS and violent SDS received per youth in a year. 
Table 1. Structure of Panel Dataset

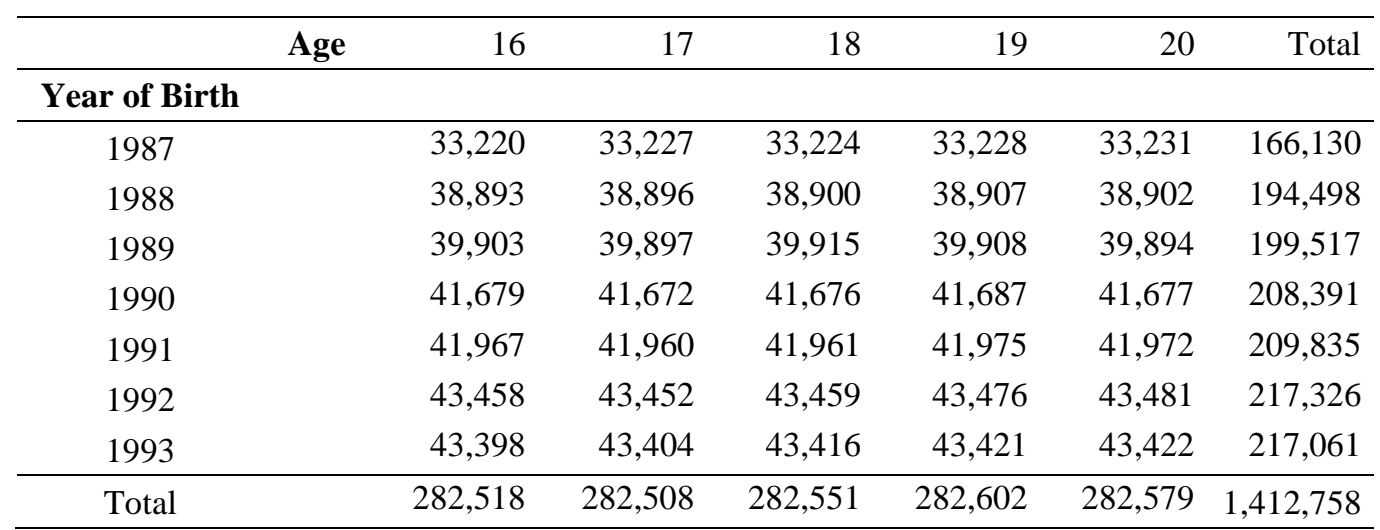

Notes: Table shows the structure of the dataset used for the entire analysis. Each unit of observation here is an individual-year. Crime offences per individual are studied at age 16-20 and School Discipline Sanctions (SDS) at age 16-17. Crime offences include property damage and theft, drugs and violence by offender in a year. Violence includes violence against the person, sexual offences, and public order offences by offender in a year. SDS include property misconduct SDS, illicit substance SDS and violent SDS received per youth in a year. 
Table 2. School Disciplinary Sanctions (SDS) Received and Crime Committed, School Years 2003 to 2013

\begin{tabular}{|c|c|c|c|c|c|c|}
\hline & Age 16 to 20 & Age 16 & Age 17 & Age 18 & Age 19 & Age 20 \\
\hline \multicolumn{7}{|l|}{ A. SDS Received } \\
\hline Number & 13,778 & 9,107 & 4,671 & & & \\
\hline Share of Age 16 to 17 & 1 & 0.661 & 0.339 & & & \\
\hline Percent Rate & 0.024 & 0.032 & 0.017 & & & \\
\hline Juveniles & & 282,702 & & & & \\
\hline Observations & & 565,026 & & & & \\
\hline \multicolumn{7}{|l|}{ B. Crime Committed } \\
\hline Number & 56,582 & 11,629 & 12,384 & 12,023 & 10,885 & 9,661 \\
\hline Share of Age 16 to 20 & 1 & 0.206 & 0.219 & 0.212 & 0.192 & 0.171 \\
\hline Percent Rate & 0.040 & 0.041 & 0.044 & 0.043 & 0.039 & 0.034 \\
\hline Juveniles & \multicolumn{6}{|c|}{282,702} \\
\hline Observations & \multicolumn{6}{|c|}{$1,412,758$} \\
\hline
\end{tabular}

Notes: Table shows the count of School Discipline Sanctions (SDS) received and crime offences committed at all ages and separately by age. The share of SDS received and crime offences committed at each age are also shown, together with the fraction of individuals who received SDS or committed crime offences at all ages and at each age separately. Crime offences include property damage and theft, drugs and violence by offender in a year. Violence includes violence against the person, sexual offences, and public order offences by offender in a year. SDS include property misconduct SDS, illicit substance SDS and violent SDS received per youth in a year. 
Table 3. Balancing of Individual Characteristics across the Earning or Learning (EL) Reform, Aged 16-17

\begin{tabular}{|c|c|c|c|c|}
\hline & \multirow[t]{2}{*}{ Impact on EL Reform on: } & OLS & $\begin{array}{l}\text { Non-Parametric RD } \\
\text { Estimates using } \\
\text { Uniform Kernel } \\
\end{array}$ & $\begin{array}{l}\text { Non-Parametric RD } \\
\text { Estimates using } \\
\text { Triangular Kernel }\end{array}$ \\
\hline & & (1) & (2) & $(3)$ \\
\hline \multirow[t]{2}{*}{ (1) } & Age & 0.000 & 0.000 & 0.000 \\
\hline & & $(0.000)$ & $(0.000)$ & $(0.000)$ \\
\hline \multirow[t]{2}{*}{ (2) } & Male & 0.003 & 0.003 & 0.003 \\
\hline & & $(0.005)$ & $(0.005)$ & $(0.006)$ \\
\hline \multirow[t]{2}{*}{ (3) } & Native Speaker & -0.004 & -0.004 & -0.002 \\
\hline & & $(0.003)$ & $(0.003)$ & $(0.004)$ \\
\hline \multirow[t]{2}{*}{ (4) } & Male * Native Speaker & 0.000 & 0.000 & -0.000 \\
\hline & & $(0.005)$ & $(0.005)$ & $(0.006)$ \\
\hline \multirow{2}{*}{ (5) } & Off Time & 0.013 & 0.013 & 0.007 \\
\hline & & $(0.012)$ & $(0.012)$ & $(0.016)$ \\
\hline (6) & Off Time * Male & 0.007 & 0.007 & 0.003 \\
\hline \multirow{2}{*}{ (7) } & Off Time * Native Speaker & 0.007 & 0.007 & 0.008 \\
\hline & & $(0.011)$ & $(0.011)$ & $(0.016)$ \\
\hline \multirow[t]{2}{*}{ (8) } & Day-Month of Birth & -2.050 & -2.050 & -2.312 \\
\hline & & $(9.606)$ & $(9.608)$ & $(13.22)$ \\
\hline \multirow[t]{2}{*}{ (9) } & Day-Month of Birth * Male & 0.269 & 0.269 & 0.080 \\
\hline & & (4.903) & (4.904) & $(6.717)$ \\
\hline \multirow[t]{5}{*}{ (10) } & Day-Month of Birth * Native Speaker & $\begin{array}{l}-2.657 \\
(8.945)\end{array}$ & $\begin{array}{l}-2.657 \\
(8.948)\end{array}$ & $\begin{array}{c}-2.695 \\
(12.318)\end{array}$ \\
\hline & Year of Birth Trend & Yes & Yes & Yes \\
\hline & Year of Birth Trend x Born 1990 & Yes & Yes & Yes \\
\hline & Juveniles & 282702 & 282702 & 282702 \\
\hline & Observations & 565026 & 565026 & 565026 \\
\hline
\end{tabular}

Notes: Presented in each row are the discontinuity estimates of the given variable at the 1990 year of birth cut-off. Estimates in column (1) are obtained from OLS regression specifications, estimates in column (2) are obtained from local linear regression specifications where a uniform kernel is used and estimates in column (3) are obtained from local linear regression specifications where a triangular kernel is used. Standard errors are clustered at the date of birth level. All specifications include distance to the 1990 cut-off and its interaction term with the post-cut-off indicator (born in $1990-93=1$ ). $* * *$ indicates significance at 1 percent, $* *$ indicates significance at 5 percent, * indicates significance at 10 percent. 
Table 4. Estimates of Impact of Earning or Learning (EL) Reform on School Disciplinary Sanctions (SDS)

\begin{tabular}{|c|c|c|c|c|c|c|c|c|c|}
\hline & \multicolumn{9}{|c|}{ Impact of EL Reform on SDS, Aged 16 to 17} \\
\hline & \multicolumn{3}{|c|}{$\begin{array}{l}\text { Property } \\
\text { SDS }\end{array}$} & \multicolumn{3}{|c|}{$\begin{array}{c}\text { Illicit Substances } \\
\text { SDS } \\
\end{array}$} & \multicolumn{3}{|c|}{$\begin{array}{l}\text { Violent } \\
\text { SDS }\end{array}$} \\
\hline & $(1)$ & $(2)$ & $(3)$ & $(4)$ & $(5)$ & $(6)$ & $(7)$ & $(8)$ & $(9)$ \\
\hline Panel A. SDS Count & $\begin{array}{l}-0.001 \\
(0.001)\end{array}$ & $\begin{array}{l}-0.001 \\
(0.001)\end{array}$ & $\begin{array}{l}-0.001 \\
(0.001)\end{array}$ & $\begin{array}{c}0.000 \\
(0.000)\end{array}$ & $\begin{array}{c}0.000 \\
(0.000)\end{array}$ & $\begin{array}{c}0.000 \\
(0.000)\end{array}$ & $\begin{array}{l}0.003 * * \\
(0.001)\end{array}$ & $\begin{array}{c}0.003 * * \\
(0.001)\end{array}$ & $\begin{array}{l}0.003 * * \\
(0.001)\end{array}$ \\
\hline Percent Effect & $-20 \%$ & $-20 \%$ & $-20 \%$ & $0 \%$ & $0 \%$ & $0 \%$ & $17.65 \%$ & $17.65 \%$ & $17.65 \%$ \\
\hline Panel B. SDS Received (0/1) & $\begin{array}{l}-0.001 \\
(0.001)\end{array}$ & $\begin{array}{l}-0.001 \\
(0.001)\end{array}$ & $\begin{array}{l}-0.001 \\
(0.001)\end{array}$ & $\begin{array}{l}-0.000 \\
(0.000)\end{array}$ & $\begin{array}{l}-0.000 \\
(0.000)\end{array}$ & $\begin{array}{c}0.000 \\
(0.000)\end{array}$ & $\begin{array}{c}0.002 * \\
(0.001)\end{array}$ & $\begin{array}{l}0.002^{* *} \\
(0.001)\end{array}$ & $\begin{array}{l}0.002 * * \\
(0.001)\end{array}$ \\
\hline Percent Effect & $-20 \%$ & $-20 \%$ & $-20 \%$ & $-0 \%$ & $-0 \%$ & $0 \%$ & $12.5 \%$ & $12.5 \%$ & $12.5 \%$ \\
\hline Mean Dependent Variable Prior to EL Reform & 0.005 & 0.005 & 0.005 & 0.002 & 0.002 & 0.002 & 0.016 & 0.016 & 0.016 \\
\hline Year of Birth Trend & Yes & Yes & Yes & Yes & Yes & Yes & Yes & Yes & Yes \\
\hline Year of Birth Trend x Born 1990 & Yes & Yes & Yes & Yes & Yes & Yes & Yes & Yes & Yes \\
\hline Age Fixed Effects & Yes & Yes & Yes & Yes & Yes & Yes & Yes & Yes & Yes \\
\hline Control Variables & No & Yes & Yes & No & Yes & Yes & No & Yes & Yes \\
\hline Date of Birth Fixed Effects & No & Yes & Yes & No & Yes & Yes & No & Yes & Yes \\
\hline School Fixed Effects & No & No & Yes & No & No & Yes & No & No & Yes \\
\hline Number of Observations & 565026 & 565026 & 565026 & 565026 & 565026 & 565026 & 565026 & 565026 & 565026 \\
\hline Number of Birthdates & 2555 & 2555 & 2555 & 2555 & 2555 & 2555 & 2555 & 2555 & 2555 \\
\hline Dropout Grade & $\begin{array}{l}0.269 * * * \\
(0.008)\end{array}$ & $\begin{array}{l}0.269 * * * \\
(0.007)\end{array}$ & $\begin{array}{l}0.268 * * * \\
(0.007)\end{array}$ & $\begin{array}{l}0.269 \text { *** } \\
(0.008)\end{array}$ & $\begin{array}{l}0.269 * * * \\
(0.007)\end{array}$ & $\begin{array}{l}0.268 * * * \\
(0.007)\end{array}$ & $\begin{array}{l}0.269 * * * \\
(0.008)\end{array}$ & $\begin{array}{l}0.269 * * * \\
(0.007)\end{array}$ & $\begin{array}{l}0.268^{* * * *} \\
(0.007)\end{array}$ \\
\hline
\end{tabular}

Notes: Table shows estimates of the causal effect of the Earning or Learning (EL) Reform on property misconduct school discipline sanctions (SDS, columns (1)(3)), illicit substances misconduct SDS (columns (4)-(6)) and violent SDS (columns (7)-(9)). Estimates are shown at the extensive and intensive margin in Panel A, and at the extensive margin in Panel B. Estimates are obtained from OLS regression specifications and standard errors were clustered at the date of birth level. Control variables included are dummies for whether the youths are male and whether they are native English speakers. *** indicates significance at $1 \%$. $* *$ indicates significance at $5 \%$. * indicates significance at $10 \%$. 
Table 5. Robustness Estimates of Impact of Earning or Learning (EL) Reform on Violent School Disciplinary Sanctions (SDS)

\begin{tabular}{|c|c|c|c|c|c|c|}
\hline & \multicolumn{6}{|c|}{ Impact of EL Reform on Violent SDS, Aged 16 to 17} \\
\hline & \multicolumn{3}{|c|}{$\begin{array}{l}\text { Non-Parametric RD Estimates } \\
\text { using Uniform Kernel }\end{array}$} & \multicolumn{3}{|c|}{$\begin{array}{c}\text { Non-Parametric RD Estimates } \\
\text { using Triangular Kernel }\end{array}$} \\
\hline & $(1)$ & $(2)$ & $(3)$ & (4) & $(5)$ & $(6)$ \\
\hline Panel A. SDS Count & $\begin{array}{l}0.003 * * * \\
(0.001)\end{array}$ & $\begin{array}{l}0.003 * * * \\
(0.001)\end{array}$ & $\begin{array}{l}0.003 * * * \\
(0.001)\end{array}$ & $\begin{array}{c}0.003 * * \\
(0.001)\end{array}$ & $\begin{array}{l}0.003 * * * \\
(0.001)\end{array}$ & $\begin{array}{l}0.003^{* * * *} \\
(0.001)\end{array}$ \\
\hline Percent Effect & $17.65 \%$ & $17.65 \%$ & $17.65 \%$ & $17.65 \%$ & $17.65 \%$ & $17.65 \%$ \\
\hline Mean Dependent Variable Prior to EL Reform & 0.017 & 0.017 & 0.017 & 0.017 & 0.017 & 0.017 \\
\hline Panel B. SDS Received (0/1) & $\begin{array}{l}0.002 * * \\
(0.001)\end{array}$ & $\begin{array}{l}0.002 * * * \\
(0.001)\end{array}$ & $\begin{array}{l}0.002 * * * \\
(0.001)\end{array}$ & $\begin{array}{l}0.003 * * \\
(0.001)\end{array}$ & $\begin{array}{l}0.003^{* * *} \\
(0.001)\end{array}$ & $\begin{array}{l}0.003 * * * \\
(0.001)\end{array}$ \\
\hline Percent Effect & $12.5 \%$ & $12.5 \%$ & $12.5 \%$ & $18.75 \%$ & $18.75 \%$ & $18.75 \%$ \\
\hline Mean Dependent Variable Prior to EL Reform & 0.016 & 0.016 & 0.016 & 0.016 & 0.016 & 0.016 \\
\hline Year of Birth Trend & Yes & Yes & Yes & Yes & Yes & Yes \\
\hline Year of Birth Trend x Born 1990 & Yes & Yes & Yes & Yes & Yes & Yes \\
\hline School-year fixed effects & Yes & Yes & Yes & Yes & Yes & Yes \\
\hline Age Fixed Effects & Yes & Yes & Yes & Yes & Yes & Yes \\
\hline Control Variables & No & Yes & Yes & No & Yes & Yes \\
\hline Date of Birth Fixed Effects & No & Yes & Yes & No & Yes & Yes \\
\hline School Fixed Effects & No & No & Yes & No & No & Yes \\
\hline Number of Observations & 565026 & 565026 & 565026 & 565026 & 565026 & 565026 \\
\hline Number of Birthdates & 2555 & 2555 & 2555 & 2555 & 2555 & 2555 \\
\hline
\end{tabular}

Notes: Table shows estimates of the causal effect of the Earning or Learning (EL) Reform on violent school discipline sanction (SDS) at the extensive and intensive margin in Panel A, and at the extensive margin in Panel B. Estimates in columns (1)-(3) are obtained from Non-Parametric RD Estimation using a Uniform Kernel, and estimates in columns (4)(6) from Non-Parametric RD Estimation using a Triangular Kernel. Standard errors were clustered at the date of birth level. Control variables included are dummies for whether the youths are male and whether they are native English speakers. *** indicates significance at $1 \%$. ** indicates significance at $5 \%$ * indicates significance at $10 \%$. 
Table 6. Robustness Estimates of Impact of Earning or Learning (EL) Reform on Violent School Disciplinary Sanctions (SDS) Without “Off Time” Students

\begin{tabular}{|c|c|c|c|}
\hline & \multicolumn{3}{|c|}{$\begin{array}{c}\text { Impact of EL Reform on Violent } \\
\text { SDS, Aged } 16 \text { to } 17\end{array}$} \\
\hline & $(1)$ & $(2)$ & $(3)$ \\
\hline Panel A. SDS Count & $\begin{array}{l}0.004 * * * \\
(0.001)\end{array}$ & $\begin{array}{l}0.004 * * * \\
(0.001)\end{array}$ & $\begin{array}{l}0.004 * * * \\
(0.001)\end{array}$ \\
\hline Percent Effect & $23.53 \%$ & $23.53 \%$ & $23.53 \%$ \\
\hline Mean Dependent Variable Prior to EL Reform & 0.017 & 0.017 & 0.017 \\
\hline Panel B. SDS Received (0/1) & $\begin{array}{l}0.004 * * * \\
(0.001)\end{array}$ & $\begin{array}{l}0.004 * * * \\
(0.001)\end{array}$ & $\begin{array}{l}0.004 * * * \\
(0.001)\end{array}$ \\
\hline Percent Effect & $25 \%$ & $25 \%$ & $25 \%$ \\
\hline Mean Dependent Variable Prior to EL Reform & 0.016 & 0.016 & 0.016 \\
\hline Year of Birth Trend & Yes & Yes & Yes \\
\hline Year of Birth Trend x Born 1990 & Yes & Yes & Yes \\
\hline School-year fixed effects & Yes & Yes & Yes \\
\hline Age Fixed Effects & Yes & Yes & Yes \\
\hline Control Variables & No & Yes & Yes \\
\hline Date of Birth Fixed Effects & No & Yes & Yes \\
\hline School Fixed Effects & No & No & Yes \\
\hline Number of Observations & 398405 & 398405 & 398405 \\
\hline Number of Birthdates & 2555 & 2555 & 2555 \\
\hline
\end{tabular}

Notes: Table shows estimates of the causal effect of the Earning or Learning (EL) Reform on violent school discipline sanctions (SDS) at the extensive and intensive margin in Panel A, and at the extensive margin in Panel B without "off time" students. "Off time" students defined as students not attending grade 10 at age 15, i.e., the expected school grade based on year of birth prior to reaching the school leaving age. Estimates are obtained from OLS regression specifications and standard errors were clustered at the date of birth level. Control variables included are dummies for whether the youths are male and whether they are native English speakers. *** indicates significance at $1 \%$. ** indicates significance at $5 \%$. $*$ indicates significance at $10 \%$. 
Table 7. Placebo Estimates of Impact of Fake Earning or Learning (EL) Reform on Violent School Disciplinary Sanctions (SDS)

\begin{tabular}{lccc}
\hline & \multicolumn{3}{c}{ Placebo Estimates of Impact of Fake EL } \\
& Reform on Violent SDS, Aged 16 to 17 \\
\hline & ITT & ITT & ITT \\
\hline & & $(1)$ & $(3)$ \\
\hline Panel A. SDS Count & -0.001 & -0.001 & -0.001 \\
& $(0.002)$ & $(0.001)$ & $(0.001)$ \\
Percent Effect & $-5.9 \%$ & $-5.9 \%$ & $-5.9 \%$ \\
Mean Dependent Variable Prior to EL Reform & 0.017 & 0.017 & 0.017 \\
& & & \\
Panel B. SDS Received (0/1) & -0.001 & -0.001 & -0.002 \\
& $(0.001)$ & $(0.001)$ & $(0.001)$ \\
Percent Effect & $-6.25 \%$ & $-6.25 \%$ & $-12.5 \%$ \\
Mean Dependent Variable Prior to EL Reform & 0.016 & 0.016 & 0.016 \\
& & & \\
Year of Birth Trend & Yes & Yes & Yes \\
Year of Birth Trend x Born 1989 & Yes & Yes & Yes \\
School-year fixed effects & Yes & Yes & Yes \\
Age Fixed Effects & Yes & Yes & Yes \\
Control Variables & No & Yes & Yes \\
Date of Birth Fixed Effects & No & Yes & Yes \\
School Fixed Effects & No & No & Yes \\
Number of Observations & & & 565026 \\
Number of Birthdates & 565026 & 565026 & 2555 \\
& 2555 & 2555 & \\
\hline
\end{tabular}

Notes: Table shows Placebo estimates of the fake causal effect of the Earning or Learning (EL) Reform shifted back to 1989 , i.e., by one birth cohort, on violent school discipline sanctions (SDS) at the extensive and intensive margin in Panel A, and at the extensive margin in Panel B. Estimates are obtained from OLS regression specifications and standard errors were clustered at the date of birth level. Control variables included are dummies for whether the youths are male and whether they are native English speakers. *** indicates significance at $1 \%$. $* *$ indicates significance at $5 \%$. * indicates significance at $10 \%$. 
Table 8. Estimates of Impact of Earning or Learning (EL) Reform on Additional School Disciplinary Sanctions (SDS)

\begin{tabular}{|c|c|c|c|c|c|}
\hline & $\begin{array}{l}\text { Truancy } \\
\text { SDS }\end{array}$ & $\begin{array}{c}\text { Verbal } \\
\text { Abuse } \\
\text { SDS }\end{array}$ & $\begin{array}{l}\text { Misconduct } \\
\text { SDS }\end{array}$ & $\begin{array}{c}\text { Disruption } \\
\text { or Refusal } \\
\text { to } \\
\text { Participate } \\
\text { SDS } \\
\end{array}$ & $\begin{array}{c}\text { Legal } \\
\text { Substances } \\
\text { SDS }\end{array}$ \\
\hline & $(1)$ & $(2)$ & (3) & $(4)$ & $(5)$ \\
\hline EL Reform & $\begin{array}{c}0.001 \\
(0.000)\end{array}$ & $\begin{array}{l}0.003 * * \\
(0.001)\end{array}$ & $\begin{array}{l}-0.000 \\
(0.001)\end{array}$ & $\begin{array}{c}0.000 \\
(0.001)\end{array}$ & $\begin{array}{l}-0.000 \\
(0.001)\end{array}$ \\
\hline Percent Effect & $50 \%$ & $17.65 \%$ & $-0 \%$ & $-0 \%$ & $-0 \%$ \\
\hline Mean Dependent Variable Prior to EL Reform & 0.002 & 0.017 & 0.008 & 0.020 & 0.008 \\
\hline Year of Birth Trend & Yes & Yes & Yes & Yes & Yes \\
\hline Year of Birth Trend x Born 1990 & Yes & Yes & Yes & Yes & Yes \\
\hline School-year fixed effects & Yes & Yes & Yes & Yes & Yes \\
\hline Age Fixed Effects & Yes & Yes & Yes & Yes & Yes \\
\hline Control Variables & Yes & Yes & Yes & Yes & Yes \\
\hline Date of Birth Fixed Effects & Yes & Yes & Yes & Yes & Yes \\
\hline School Fixed Effects & Yes & Yes & Yes & Yes & Yes \\
\hline Number of Observations & 565026 & 565026 & 565026 & 565026 & 565026 \\
\hline Number of Birthdates & 2555 & 2555 & 2555 & 2555 & 2555 \\
\hline
\end{tabular}

Notes: Table shows estimates of the causal effect of the Earning or Learning (EL) Reform on other categories of school discipline sanctions (SDS) at the extensive and intensive margin not included in the main analysis. Estimates are obtained from OLS regression specifications and standard errors were clustered at the date of birth level. Control variables included are dummies for whether the youths are male and whether they are native English speakers. $* * *$ indicates significance at $1 \%$. $* *$ indicates significance at $5 \%$. ${ }^{*}$ indicates significance at $10 \%$. 


\section{Table 9. Robustness Estimates of Impact of Earning or Learning (EL) Reform on Violent School Disciplinary Sanctions (SDS)}

\begin{tabular}{|c|c|c|c|c|c|}
\hline & \multicolumn{2}{|c|}{$\begin{array}{c}\text { Impact of EL Reform } \\
\text { on Violent SDS, } \\
\text { Aged } 16 \text { to } 17\end{array}$} & \multicolumn{3}{|c|}{$\begin{array}{l}\text { Impact of EL Reform on Violent } \\
\text { SDS, 1988-93 cohorts Aged } 15\end{array}$} \\
\hline & $(1)$ & $(2)$ & $(3)$ & (4) & $(5)$ \\
\hline Panel A. SDS Count & $\begin{array}{l}0.003 * * \\
(0.001)\end{array}$ & $\begin{array}{l}0.003 * * \\
(0.001)\end{array}$ & $\begin{array}{l}0.005^{* *} \\
(0.003)\end{array}$ & $\begin{array}{l}0.005^{* *} \\
(0.002)\end{array}$ & $\begin{array}{l}0.006 * * \\
(0.002)\end{array}$ \\
\hline Percent Effect & $17.65 \%$ & $17.65 \%$ & $12.5 \%$ & $12.5 \%$ & $15 \%$ \\
\hline Mean Dependent Variable Prior to EL Reform & 0.017 & 0.017 & 0.040 & 0.040 & 0.040 \\
\hline Panel B. SDS Received (0/1) & $\begin{array}{l}0.002 * * \\
(0.001)\end{array}$ & $\begin{array}{l}0.002 * * \\
(0.001)\end{array}$ & $\begin{array}{c}0.003 \\
(0.002)\end{array}$ & $\begin{array}{c}0.003 \\
(0.002)\end{array}$ & $\begin{array}{c}0.003 \\
(0.002)\end{array}$ \\
\hline Percent Effect & $12.5 \%$ & $12.5 \%$ & $8.3 \%$ & $8.3 \%$ & $8.3 \%$ \\
\hline Mean Dependent Variable Prior to EL Reform & 0.016 & 0.016 & 0.036 & 0.036 & 0.036 \\
\hline Year of Birth Trend & Yes & Yes & Yes & Yes & Yes \\
\hline Year of Birth Trend x Born 1990 & Yes & Yes & Yes & Yes & Yes \\
\hline School-year fixed effects & Yes & Yes & No & No & No \\
\hline Age Fixed Effects & Yes & Yes & No & No & No \\
\hline Control Variables & Yes & Yes & No & Yes & Yes \\
\hline Date of Birth Fixed Effects & Yes & Yes & No & Yes & Yes \\
\hline School Fixed Effects & Yes & Yes & No & No & Yes \\
\hline School Fixed Effects x (School Year >= 2006) & Yes & No & No & No & No \\
\hline School Fixed Effects x School-year fixed effects & No & Yes & No & No & No \\
\hline Number of Observations & 565026 & 565026 & 249289 & 249289 & 249289 \\
\hline Number of Birthdates & 2555 & 2555 & 2190 & 2190 & 2190 \\
\hline
\end{tabular}

Notes: Table shows estimates of the causal effect of the Earning or Learning (EL) Reform on violent school discipline sanctions (SDS) at the extensive and intensive margin in Panel A, and at the extensive margin in Panel B. Estimates are obtained from OLS regression specifications and standard errors were clustered at the date of birth level. Control variables included are dummies for whether the youths are male and whether they are native English speakers. $* * *$ indicates significance at $1 \%$. $*$ indicates significance at $5 \%$. $*$ indicates significance at $10 \%$. 
Table 10. Estimates of Impact of Earning or Learning (EL) Reform on Crime and School Disciplinary Sanctions (SDS)

\begin{tabular}{|c|c|c|c|c|c|c|c|c|c|}
\hline & \multicolumn{9}{|c|}{ Impact of EL Reform on Crime and SDS } \\
\hline & $\begin{array}{l}\text { Property } \\
\text { Crime, } \\
\text { Aged } \\
18-20\end{array}$ & $\begin{array}{l}\text { Property } \\
\text { Crime, } \\
\text { Aged } \\
16-17\end{array}$ & $\begin{array}{l}\text { Property } \\
\text { SDS, } \\
\text { Aged } \\
16-17\end{array}$ & $\begin{array}{c}\text { Drugs } \\
\text { Crime, } \\
\text { Aged } \\
18-20\end{array}$ & $\begin{array}{c}\text { Drugs } \\
\text { Crime, } \\
\text { Aged } \\
16-17\end{array}$ & $\begin{array}{l}\text { Drugs } \\
\text { SDS, } \\
\text { Aged } \\
16-17\end{array}$ & $\begin{array}{c}\text { Violent } \\
\text { Crime, } \\
\text { Aged } \\
18-20\end{array}$ & $\begin{array}{l}\text { Violent } \\
\text { Crime, } \\
\text { Aged } \\
16-17\end{array}$ & $\begin{array}{l}\text { Violent } \\
\text { SDS, } \\
\text { Aged } \\
16-17\end{array}$ \\
\hline & ITT & ITT & ITT & ITT & ITT & ITT & ITT & ITT & ITT \\
\hline & $(1)$ & $(2)$ & $(3)$ & $(4)$ & $(5)$ & $(6)$ & $(7)$ & $(8)$ & $(9)$ \\
\hline Panel A. Crime or SDS Count & $\begin{array}{l}-0.011 * \\
(0.006)\end{array}$ & $\begin{array}{l}-0.021^{* *} \\
(0.010)\end{array}$ & $\begin{array}{l}-0.001 \\
(0.001)\end{array}$ & $\begin{array}{l}-0.006^{* * *} \\
(0.002)\end{array}$ & $\begin{array}{l}-0.003 * \\
(0.002)\end{array}$ & $\begin{array}{c}0.000 \\
(0.000)\end{array}$ & $\begin{array}{l}-0.001 \\
(0.001)\end{array}$ & $\begin{array}{l}-0.000 \\
(0.001)\end{array}$ & $\begin{array}{l}0.003^{* *} \\
(0.001)\end{array}$ \\
\hline Percent Effect & $-21.15 \%$ & $-26.58 \%$ & $-20 \%$ & $-18.75 \%$ & $-15 \%$ & $0 \%$ & $-9.09 \%$ & $-0 \%$ & $17.65 \%$ \\
\hline Mean Dependent Variable Prior to EL Reform & 0.052 & 0.079 & 0.005 & 0.032 & 0.020 & 0.002 & 0.011 & 0.010 & 0.017 \\
\hline Panel B. Crime or SDS Occurrence $(0 / 1)$ & $\begin{array}{l}-0.002 * * \\
(0.001)\end{array}$ & $\begin{array}{l}-0.003 * * \\
(0.001)\end{array}$ & $\begin{array}{l}-0.001 \\
(0.001)\end{array}$ & $\begin{array}{l}-0.003 * * * \\
(0.001)\end{array}$ & $\begin{array}{l}-0.003 * * * \\
(0.001)\end{array}$ & $\begin{array}{c}0.000 \\
(0.000)\end{array}$ & $\begin{array}{l}-0.001 \\
(0.001)\end{array}$ & $\begin{array}{c}0.000 \\
(0.001)\end{array}$ & $\begin{array}{l}0.002 * * \\
(0.001)\end{array}$ \\
\hline Percent Effect & $-10 \%$ & $-10.34 \%$ & $-20 \%$ & $-16.67 \%$ & $-25 \%$ & $0 \%$ & $-12.5 \%$ & $0 \%$ & $12.5 \%$ \\
\hline Year of Birth Trend & Yes & Yes & Yes & Yes & Yes & Yes & Yes & Yes & Yes \\
\hline Year of Birth Trend x Born 1990 & Yes & Yes & Yes & Yes & Yes & Yes & Yes & Yes & Yes \\
\hline School-year fixed effects & Yes & Yes & Yes & Yes & Yes & Yes & Yes & Yes & Yes \\
\hline Age Fixed Effects & Yes & Yes & Yes & Yes & Yes & Yes & Yes & Yes & Yes \\
\hline Control Variables & Yes & Yes & Yes & Yes & Yes & Yes & Yes & Yes & Yes \\
\hline Date of Birth Fixed Effects & Yes & Yes & Yes & Yes & Yes & Yes & Yes & Yes & Yes \\
\hline School Fixed Effects & Yes & Yes & Yes & Yes & Yes & Yes & Yes & Yes & Yes \\
\hline Number of Observations & 847732 & 565026 & 565026 & 847732 & 565026 & 565026 & 847732 & 565026 & 565026 \\
\hline Number of Birthdates & 2555 & 2555 & 2555 & 2555 & 2555 & 2555 & 2555 & 2555 & 2555 \\
\hline Impact of EL Reform on Dropout Grade & $\begin{array}{l}0.313 \text { *** } \\
(0.007)\end{array}$ & $\begin{array}{l}0.268 \text { *** } \\
(0.007)\end{array}$ & $\begin{array}{l}0.268 * * * \\
(0.007)\end{array}$ & $\begin{array}{l}0.313^{* * *} \\
(0.007)\end{array}$ & $\begin{array}{l}0.268^{* * * *} \\
(0.007)\end{array}$ & $\begin{array}{l}0.268 * * * \\
(0.007)\end{array}$ & $\begin{array}{l}0.313 \text { *** } \\
(0.007)\end{array}$ & $\begin{array}{l}0.268 * * * \\
(0.007)\end{array}$ & $\begin{array}{l}0.268 * * * \\
(0.007)\end{array}$ \\
\hline
\end{tabular}

Notes: Table shows estimates of the causal effect of the Earning or Learning (EL) Reform on crime and school discipline sanctions (SDS) at the extensive and intensive margin in Panel A, and at the extensive margin in Panel B. Estimates are obtained from OLS regression specifications and standard errors were clustered at the date of birth level. Control variables included are dummies for whether the youths are male and whether they are native English speakers. Crime offences include property damage and theft, drugs and violence by offender in a year. Violence includes violence against the person, sexual offences, and public order offences by offender in a year. SDS include property misconduct SDS, illicit substance SDS and violent SDS received per youth in a year. *** indicates significance at $1 \%$. ** indicates significance at $5 \%$. $*$ indicates significance at $10 \%$. 
Table 11. Impact of Earning or Learning (EL) Reform on Individual and School Characteristics of Juveniles in School, Aged 16-17

\begin{tabular}{|c|c|c|c|c|c|c|c|c|c|}
\hline & Male & $\begin{array}{l}\text { Native } \\
\text { Speaker }\end{array}$ & $\begin{array}{c}\text { Male } \\
\text { Native } \\
\text { Speaker }\end{array}$ & Off Time & $\begin{array}{l}\text { Off Time } \\
\text { Male }\end{array}$ & $\begin{array}{l}\text { Off Time } \\
\text { Native } \\
\text { Speaker }\end{array}$ & $\begin{array}{l}\text { Male Share } \\
\text { in Class }\end{array}$ & $\begin{array}{l}\text { Class } \\
\text { Size }\end{array}$ & $\begin{array}{c}\text { School } \\
\text { Deprivation } \\
\text { Index } \\
\end{array}$ \\
\hline & $(1)$ & (2) & $(3)$ & (4) & $(5)$ & $(6)$ & (7) & $(8)$ & $(9)$ \\
\hline EL Reform & $\begin{array}{l}0.037 * * * \\
(0.005)\end{array}$ & $\begin{array}{l}0.055^{* * *} \\
(0.005)\end{array}$ & $\begin{array}{l}0.035 * * * \\
(0.005)\end{array}$ & $\begin{array}{l}0.020^{*} \\
(0.011)\end{array}$ & $\begin{array}{l}0.012 * \\
(0.006)\end{array}$ & $\begin{array}{l}0.022 * * \\
(0.010)\end{array}$ & $\begin{array}{l}0.022 * * * \\
(0.003)\end{array}$ & $\begin{array}{l}4.771 * * * \\
(1.794)\end{array}$ & $\begin{array}{l}0.454 * * * \\
(0.050)\end{array}$ \\
\hline Percent Effect & $9.39 \%$ & $7.40 \%$ & $9.56 \%$ & $8.85 \%$ & $9.76 \%$ & $10.84 \%$ & $8.15 \%$ & $5.23 \%$ & $6.25 \%$ \\
\hline $\begin{array}{l}\text { Mean Dependent Variable Prior to } \\
\text { EL Reform }\end{array}$ & 0.394 & 0.743 & 0.366 & 0.226 & 0.123 & 0.203 & 0.270 & 91.188 & 7.268 \\
\hline Year of Birth Trend & Yes & Yes & Yes & Yes & Yes & Yes & Yes & Yes & Yes \\
\hline Year of Birth Trend x Born 1990 & Yes & Yes & Yes & Yes & Yes & Yes & Yes & Yes & Yes \\
\hline School-year fixed effects & Yes & Yes & Yes & Yes & Yes & Yes & Yes & Yes & Yes \\
\hline Age Fixed Effects & Yes & Yes & Yes & Yes & Yes & Yes & Yes & Yes & Yes \\
\hline Juveniles & 282702 & 282702 & 282702 & 282702 & 282702 & 282702 & 282702 & 282702 & 282702 \\
\hline Observations & 565026 & 565026 & 565026 & 565026 & 565026 & 565026 & 565026 & 565026 & 565026 \\
\hline
\end{tabular}

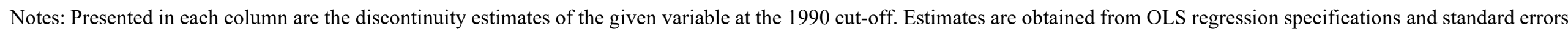

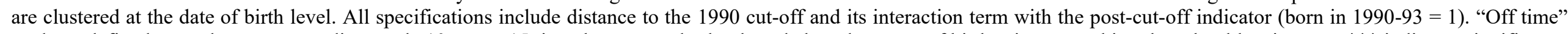

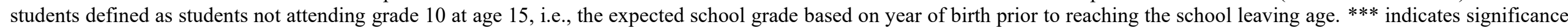
at 1 percent, $* *$ indicates significance at 5 percent, $*$ indicates significance at 10 percent. 
APPENDIX 
Figure A.1. UK Media Coverage on the Potential for Compulsory Schooling to Increase Violence in School.

- Exclusive: Keeping pupils in educ $\times+$
$\leftarrow \rightarrow C \rightarrow$ telegraph.co.uk/news/2020/02/07/exclusive-keeping-pupils-education-age-18-iscontributing-rising/

:i: App Impostazioni of Outlookcom - Post... Nuova scheda

The Telegraph News Politics Sport Business Money Opinion Tech Life Style Travel c Q

UKnews $\sim$ World news $\checkmark$ Royals $\vee$ Health Defence Science Education Investigations $\vee$

Exclusive: Keeping pupils in education until age 18 is contributing to rising crime, police chief says

Chief Constable calls for a review into the policy as he urges minister to consider link with explosion in violent crime among youngsters

By Camilla Turner, EDUCATION EDTTOR

7 February $2020 \cdot 10: 00 \mathrm{pm}$

Related Topics
Education News

- $f \circ \square$

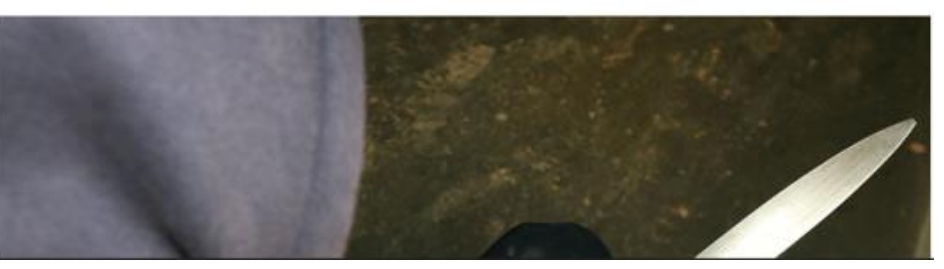


CENTRE FOR ECONOMIC PERFORMANCE

Recent Discussion Papers

\begin{tabular}{|c|c|c|}
\hline 1726 & $\begin{array}{l}\text { Maximilian v. Ehrlich } \\
\text { Henry G. Overman }\end{array}$ & $\begin{array}{l}\text { Place-based policies and spatial disparities } \\
\text { across European cities }\end{array}$ \\
\hline 1725 & $\begin{array}{l}\text { Gabriel M. Ahlfeldt } \\
\text { Thilo N. H. Albers } \\
\text { Kristian Behrens }\end{array}$ & Prime Locations \\
\hline 1724 & $\begin{array}{l}\text { Benjamin Handel } \\
\text { Jonathan Kolstad } \\
\text { Thomas Minten } \\
\text { Johannes Spinnewijn }\end{array}$ & $\begin{array}{l}\text { The Social Determinants of Choice Quality: } \\
\text { Evidence from Health Insurance in the } \\
\text { Netherlands }\end{array}$ \\
\hline 1723 & $\begin{array}{l}\text { Claudia Hupkau } \\
\text { Barbara Petrongolo }\end{array}$ & $\begin{array}{l}\text { Work, Care and Gender During the Covid-19 } \\
\text { Crisis }\end{array}$ \\
\hline 1722 & $\begin{array}{l}\text { Ross Levine } \\
\text { Yona Rubinstein }\end{array}$ & $\begin{array}{l}\text { Selection Into Entrepreneurship and Self- } \\
\text { Employment }\end{array}$ \\
\hline 1721 & Sandra McNally & $\begin{array}{l}\text { Gender Differences in Tertiary Education: } \\
\text { What Explains STEM Participation? }\end{array}$ \\
\hline 1720 & $\begin{array}{l}\text { Edoardo di Porto } \\
\text { Paolo Naticchioni } \\
\text { Vincenzo Scrutinio }\end{array}$ & $\begin{array}{l}\text { Partial Lockdown and the Spread of Covid- } \\
\text { 19: Lessons From the Italian Case }\end{array}$ \\
\hline 1719 & $\begin{array}{l}\text { Swati Dhingra } \\
\text { Stephen Machin }\end{array}$ & The Crisis and Job Guarantees in Urban India \\
\hline 1718 & Stephen J. Redding & Trade and Geography \\
\hline 1717 & $\begin{array}{l}\text { Arun Advani } \\
\text { Felix Koenig } \\
\text { Lorenzo Pessina } \\
\text { Andy Summers }\end{array}$ & $\begin{array}{l}\text { Importing Inequality: Immigration and the } \\
\text { Top } 1 \text { Percent }\end{array}$ \\
\hline
\end{tabular}




\begin{tabular}{|c|c|c|}
\hline 1716 & $\begin{array}{l}\text { Pol Antràs } \\
\text { Stephen J. Redding } \\
\text { Esteban Rossi-Hansberg }\end{array}$ & Globalization and Pandemics \\
\hline 1715 & $\begin{array}{l}\text { Davin Chor } \\
\text { Kalina Manova } \\
\text { Zhihong Yu }\end{array}$ & $\begin{array}{l}\text { Growing Like China: Firm Performance and } \\
\text { Global Production Line Position }\end{array}$ \\
\hline 1714 & $\begin{array}{l}\text { Luna Bellani } \\
\text { Anselm Hager } \\
\text { Stephan E. Maurer }\end{array}$ & $\begin{array}{l}\text { The Long Shadow of Slavery: The Persistence } \\
\text { of Slave Owners in Southern Law-Making }\end{array}$ \\
\hline 1713 & $\begin{array}{l}\text { Mathias Huebener } \\
\text { Nico A. Siegel } \\
\text { C. Katharina Spiess } \\
\text { Gert G. Wagner } \\
\text { Sevrin Waights }\end{array}$ & $\begin{array}{l}\text { Parental Well-Being in Times of Covid-19 in } \\
\text { Germany }\end{array}$ \\
\hline 1712 & $\begin{array}{l}\text { Alan Manning } \\
\text { Graham Mazeine }\end{array}$ & $\begin{array}{l}\text { Subjective Job Insecurity and the Rise of the } \\
\text { Precariat: Evidence from the UK, Germany } \\
\text { and the United States }\end{array}$ \\
\hline 1711 & $\begin{array}{l}\text { Felipe Carozzi } \\
\text { Sandro Provenzano } \\
\text { Sefi Roth }\end{array}$ & Urban Censity and Covid-19 \\
\hline 1710 & $\begin{array}{l}\text { Jonas Jessen } \\
\text { C. Katharina Spiess } \\
\text { Sevrin Waights }\end{array}$ & Center-Based Care and Parenting Activities \\
\hline 1709 & $\begin{array}{l}\text { Christos Genakos } \\
\text { Felix Grey } \\
\text { Robert A. Ritz }\end{array}$ & $\begin{array}{l}\text { Generalized Linear Competition: From Pass- } \\
\text { Through to Policy }\end{array}$ \\
\hline 1708 & $\begin{array}{l}\text { Benny Kleinman } \\
\text { Ernest Liu } \\
\text { Stephen J. Redding }\end{array}$ & International Friends and Enemies \\
\hline
\end{tabular}

The Centre for Economic Performance Publications Unit

Tel: +44 (0)2079557673 Email info@cep.lse.ac.uk

Website: http://cep.lse.ac.uk Twitter: @CEP_LSE 